\title{
Dioctahedral mixed K-Na-micas and paragonite in diagenetic to low-temperature metamorphic terrains: bulk rock chemical, thermodynamic and textural constraints
}

\section{Péter Árkai}

Institute for Geochemical Research,

Hungarian Academy of Sciences, Budapest

\section{Kenneth J. T. Livi}

The Morton K. Blaustein Department of Earth and Planetary Sciences, Johns Hopkins University, Baltimore

Péter Horváth

Institute for Geochemical Research,

Hungarian Academy of Sciences, Budapest

\begin{abstract}
Metamorphic mineral assemblages in low-temperature metaclastic rocks often contain paragonite and/or its precursor metastable phase (mixed K-Na-white mica). Relationships between the bulk rock major element chemistries and the formation of paragonite at seven localities from Central and SEEurope were studied, comparing the bulk chemical characteristics with mineral assemblage, mineral chemical and metamorphic petrological data. Considerable overlaps between the projection fields of bulk chemistries of the Pg-free and Pg-bearing metaclastic rocks indicate significant differences between the actual (as analyzed) and effective bulk chemical compositions. Where inherited, clastic, inert phases/constituents were excluded, it was found that a decrease in $\mathrm{Na} /\left(\mathrm{Na}+\mathrm{Al}^{*}\right)$ and in $\mathrm{K} /\left(\mathrm{K}+\mathrm{Al}^{*}\right)$ ratios of rocks favors the formation and occurrence of $\mathrm{Pg}$ and its precursor phases ( $\mathrm{Al}^{*}$ denotes here the atomic quantity of aluminum in feldspars, white micas and "pure" hydrous or anhydrous aluminosilicates). In contrast to earlier suggestions, enrichment in $\mathrm{Na}$ and/or an increase in $\mathrm{Na} / \mathrm{K}$ ratio by themselves do not lead to formation of paragonite. Bulk rock chemistries favorable to formation of paragonite and its precursor phases are characterized by enrichment in $\mathrm{Al}$ and depletion in $\mathrm{Na}, \mathrm{K}, \mathrm{Ca}$ (and also, $\mathrm{Mg}$ and $\mathrm{Fe}^{2+}$ ). Such bulk rock chemistries are characteristic of chemically "mature" (strongly weathered) source rocks of the pelites and may also be formed by synand post-sedimentary magmatism-related hydrothermal (leaching) activity. What part of the whole rock is active in determining the effective bulk chemistry was investigated by textural examination of diagenetic and anchizone-grade samples. It is hypothesized that although solid phases act as local sources and sinks, transport of elements such as Na through the grain boundaries have much larger communication distances. Sodium-rich white micas nucleate heterogeneously using existing phyllosilicates as templates and are distributed widely on the thin section scale. The results of modeling by THERMOCALC suggest that paragonite preferably forms at higher pressures in low-T metapelites. The stability fields of Pg-bearing assemblages increase, the Pg-in reaction line is shifted
\end{abstract}

Addresses: P. Árkai, P. Horváth: H-1112 Budapest, Budaörsi út 45, Hungary e-mails: arkai@geochem.hu,phorvath@geochem.hu K. J. T. Livi: MD 21218 USA, e-mail: klivi@jhu.edu Corresponding author: Péter Árkai

Received: October 22, 2008, accepted: January 22, 2009 
towards lower pressures, while the stability field of the Chl-Ms-Ab-Qtz assemblage decreases and is shifted towards higher temperatures with increasing $\mathrm{Al}^{*}$ content and decreasing $\mathrm{Na} /\left(\mathrm{Na}+\mathrm{Al}^{*}\right)$ and $\mathrm{K} /\left(\mathrm{K}+\mathrm{Al}^{*}\right)$ ratios.

Key words: paragonite, mixed K-Na-white mica, muscovite, low-temperature metamorphism, metapelite, bulk rock chemistry, thermobarometry

\section{Introduction}

On the basis of routine X-ray powder diffractometric (XRPD) studies carried out systematically in sedimentary basins and in the outer (fold-and-thrust) parts of orogenic belts in the second half of the last century, it was generally accepted that the overwhelming majority of the low-temperature metamorphic clastites (pelitic and marly slates and phyllites) contained a non-diagnostic, rather simple mineral assemblage of illite-muscovite, chlorite, quartz \pm feldspars, carbonate minerals, pyrite, organic matter or hematite. According to an early estimate of Frey (1987a), more than 95\% of the very low-grade metamorphic fine-grained metaclastites contain such assemblages. In the last two decades, however, the increasing application of advanced electron microbeam techniques (SEM, TEM, HRTEM, electron diffraction) combined with wave- and energy-dispersive X-ray analytical methods (EPMA, etc.) and electron energy loss spectrometry (EELS) has revealed that dioctahedral micas with mixed $\left(\mathrm{K}, \mathrm{Na}, \mathrm{Ca}, \mathrm{NH}_{4}\right)$ interlayer cation occupancy and paragonite are much more widespread in low-T metaclastites than it had been anticipated before (for reviews see Merriman and Peacor 1999; Merriman and Frey 1999; Árkai 2002).

Although the steps of reaction progress of these phyllosilicates and their precursor phases have been understood fairly well (Livi et al. 1990; Li et al. 1994; Livi et al.1997), little work has been published dealing with the distinctive cause of their occurrences, i.e. which metaclastites do or do not contain paragonite and its precursor phases. The main aims of the present study are to discuss the occurrences of paragonite and dioctahedral mica-like structures with mixed interlayer occupancy as a function of bulk rock chemistry, to determine what portion of a rock contributes to an effective bulk composition based on the local equilibrium concept, and to determine the stability fields of paragonite-bearing metamorphic assemblages using thermodynamic calculations.

\section{Previous data and models: an overview}

Paragonite has been conventionally considered a metamorphic mineral, the first appearance of which indicates - with other minerals - the beginning of metamorphism (see e.g. Winkler 1979, p. 11). Tentative reactions such as Ab + Kln $\rightarrow \mathrm{Pg}+\mathrm{Qtz}+\mathrm{H}_{2} \mathrm{O}$ (Zen 1960), and Na-Mnt $+\mathrm{Ab} \rightarrow \mathrm{Pg}+$ Qtz (Chatterjee 1973) were suggested for explaining the first occurrence of paragonite (Table 1 contains the abbreviations of mineral names after Siivola and Schmid (2007) used here and 
through the entire paper. Minerals for which no adequate symbols were found are abbreviated using other symbols, indicated with italics in Table 1.) Using

Table 1

Abbreviations of mineral names used in the present paper after Siivola and Schmid (2007)

\begin{tabular}{|c|c|c|c|}
\hline Abbreviation & Mineral name & Abbreviation & Mineral name \\
\hline $\mathrm{Ab}$ & albite & Kfs & K-feldspar \\
\hline Act & actinolite & KIn & kaolinite \\
\hline Ank & ankerite & Ky & kyanite \\
\hline $\mathrm{Bt}$ & biotite & Lws & lawsonite \\
\hline Brm & brammallite & Mgs & magnesite \\
\hline Cal & calcite & Mnt & montmorillonite \\
\hline Chl & chlorite & Mrg & margarite \\
\hline Cld & chloritoid & Ms & muscovite \\
\hline Corr & corrensite & $\mathrm{Nac}$ & nacrite \\
\hline Cro & crossite & $O M$ & organic matter \\
\hline Cph & carpholite & Omp & omphacite \\
\hline Dick & dickite & $\mathrm{Pg}$ & paragonite \\
\hline Dbs & donbassite & $\mathrm{Pg} / \mathrm{Ms}$ & paragonite/muscovite* \\
\hline Dol & dolomite & $\mathrm{Prl}$ & pyrophyllite \\
\hline Ep & epidote & Py & pyrite \\
\hline Gln & glaucophane & Qtz & quartz \\
\hline Grt & garnet & $\operatorname{Rec}$ & rectorite \\
\hline Gt & goethite & Rt & rutile \\
\hline Hem & hematite & $\mathrm{Sd}$ & siderite \\
\hline Hys & halloysite & Sme & smectite \\
\hline III & illite & St & staurolite \\
\hline III-Ms & illite-muscovite & Sud & sudoite \\
\hline I/S & illite/smectite & $\operatorname{Tr}$ & tremolite \\
\hline Jd & jadeite & Zo & zoisite \\
\hline WM & white mica & & \\
\hline MWM & dioctahedral mi & la mica** & \\
\hline \multicolumn{4}{|c|}{$\begin{array}{l}\text { (With italics those minerals are given the abbreviations of which are not } \\
\text { available in the cited work) } \\
\text { * - mixed-layered mineral sensu Frey (1969) }\end{array}$} \\
\hline \multicolumn{4}{|c|}{ ** - white mica with domainal structure sensu Livi et al. $(1997,2008)$} \\
\hline
\end{tabular}

thermodynamic calculations, the first reaction above proved to be metastable because of unrealistic low temperatures and pressures (Frey 1987a). Frey (1969, 1978) carried out extensive studies on the diagenetic to low-grade metapelite and marl of the Helvetic zone in the Swiss Central Alps. He concluded that instead of the direct, simple reaction of Na-Mnt $+\mathrm{Ab} \rightarrow \mathrm{Pg}+\mathrm{Qtz}$, a progressive reaction series of irregular mixed-layer I/S $\rightarrow$ (regular mixed-layer I/S: rectorite) $\rightarrow$ regular mixed-layer $\mathrm{Pg} / \mathrm{Ms} \rightarrow$ discrete $\mathrm{Pg}$ and Ms was supported by field evidence. The mixed-layer nature of $\mathrm{Pg} / \mathrm{Ms}$ was determined by Frey (1978) using XRPD exclusively. Paragonite/muscovite is a typical anchizonal (very low-grade metamorphic) mineral, occurring rarely also in late diagenetic, and more 
frequently in low-epizonal conditions. Qtz, $\mathrm{Pg}$, Ill or $\mathrm{Ms}$ and $\mathrm{Chl}$ are very common, Prl, Ab, Cal, Dol, Cld, Hem and organic matter common, and Kln, randomly interstratified I/S, Rec, Mrg, Mgs, Sd and Mn-rich Grt are rare coexisting minerals (Frey 1987a). In addition to greenschist facies (epizonal) occurrences, paragonite is common also in anchimetamorphic pelitic, marly slate (Frey 1987a). Paragonite may occur also in very low- and low-grade metabasites, namely in greenschist at high pressures and in blueschist. Brown (1977 in Winkler 1979) described an assemblage of Lws + Cro + Pg that formed from the assemblage of $\mathrm{Ep}+\mathrm{Chl}+\mathrm{Ab}+\mathrm{H}_{2} \mathrm{O}$. The Act $+\mathrm{Pg}$ assemblage forms above ca. $6 \mathrm{kbar}$, and the reaction is insensitive to temperature. According to Bucher and Frey (2002) the Gln + Pg $\rightarrow$ Grt + Omp reaction represents the boundary between blueschist and eclogite facies.

Guidotti and Sassi (1976) discussed the metamorphic pressure-indicating role of the $b$ [more precisely, $\left.b=6 \times\left(\mathrm{d}_{060}, \overline{3} 31\right)\right]$ values of low-grade metamorphic Kwhite micas as a function of bulk rock chemistry and mineral composition. Plotting the bulk rock and mineral chemistries in the AKNa ternary diagram constructed after Thompson (1961), and Thompson and Thompson (1976), and assuming also excess $\mathrm{SiO}_{2}$ and $\mathrm{H}_{2} \mathrm{O}$, Guidotti and Sassi (1976) stated that the $b$ value, and consequently the measure of celadonitic (using the present-day nomenclature, the aluminoceladonitic) substitution in K-white mica, increases with decreasing $\mathrm{Al}$ content of the rock. As can be deduced from the AKNa ternary plot of Guidotti and Sassi (1976), the probability of formation of Pg (or mixed $\mathrm{Pg} / \mathrm{Ms}$ ) and Prl or other Al-rich metamorphic minerals increases with an increasing ratio of $\mathrm{Al} /$ other major elements of a given rock. This statement was confirmed by Kisch et al. (2006) for HP/LT metapelites, completing the evaluation with Al-rich, $\mathrm{Fe}$ - and $\mathrm{Mg}$-containing metamorphic phases such as $\mathrm{Cld}$ and/or $\mathrm{Cph}, \mathrm{Jd}, \mathrm{Gln}$. Note, however that the presence or absence of chlorite were not considered by these authors in this context. Árkai (1982) stated that the modal amount and Al-content of other Al-bearing minerals, firstly chlorite, should be taken into consideration when the effect of bulk rock chemistry on K-white mica chemistry is evaluated using the AKNa diagram.

Spear (1995), using the results of Thompson (1974) and Thompson and Thompson (1976) discussed the phase relations of pelitic rocks in the CKNASH system and its subsystems, emphasizing the bulk rock chemistry influence on the formation of Ms, Pg and alkali feldspars. The conclusions were similar to those given by Guidotti and Sassi (1976). The Pg-out reactions with increasing P and T were given in detail. However, the Pg-in reactions at very low- and lowtemperatures and pressures are missing from the extensive summary study of Spear (1995) that focuses on P-T conditions generally higher those of the very low- and low-grade realms. Árkai and Lelkes-Felvári (1993) studied the distribution of Ms, discrete $\mathrm{Pg}$ and "mixed-layer" $\mathrm{Pg} / \mathrm{Ms}$ in a Paleozoic variegated clastic sequence from the Transdanubian Central Range (Hungary) that records Variscan anchizonal regional metamorphism. Electron probe microanalyses 
revealed irregularly varying $\mathrm{Na} / \mathrm{K}$ ratios within the white mica lamellae, indicating that the "mixed-layer $\mathrm{Pg} / \mathrm{Ms}$ " might be even a mixed Na-K-mica. The presence, absence and relative abundance of these minerals were determined using the intensity ratios of their near-2- $\AA$ (00.10) XRPD basal reflections. Linear correlation coefficients and regression equations were calculated between these XRPD parameters and components, ratios of bulk rock chemistries.

The paper of Jiang and Peacor (1993) cast doubt on the so-called 6:4 regular mixed-layer $\mathrm{Pg} / \mathrm{Ms}$ described originally by Frey (1978), stating that "micas that have XRD patterns lacking superlattice reflections have been misidentified". Combining XRPD, SEM, TEM and AEM methods for studying mica aggregates from Ordovician, hydrothermally altered metabasalt from Wales, Jiang and Peacor proved that these aggregates consist of intergrowths of subparallel stacks of Ms, Na-K intermediate micas and $\mathrm{Pg}$, with some interfaces oblique to the basal planes. Mixed-layering of micas was not observed. Studying Silurian low-T anchizonal mudrocks from Wales by XRPD, TEM and AEM methods, Li et al. (1994) demonstrated that the so called 6:4 ordered mixed-layer Pg/Ms originally described by Frey (1978) corresponds to an interlayer cation-disordered, homogeneous white mica of intermediate composition. This mineral formed from smectite by burial diagenesis. With increasing metamorphism discrete, stable Pg and Ms grains formed.

Livi et al. (1997) re-investigated the Liassic black shale from Central Switzerland, those samples in which the mixed-layer $\mathrm{Pg} / \mathrm{Ms}$ was originally described by Frey $(1969,1978)$ on the basis of XRPD data. They stated that XRPD alone could not discriminate between mixed-layer $\mathrm{Ms} / \mathrm{Pg}$ and a homogeneous, compositionally intermediate solid solution phase. Pg was found first to appear as an interlayer-deficient brammallite mixed with Ms in nanometer scale in deep diagenetic or low anchizonal conditions. As deduced from TEM observations, irregularly shaped domains of Na- and K-rich micas with sizes below $10 \mathrm{~nm}$ exist in anchizonal conditions. At higher (epizonal) grades coarsening of the domains produced discrete, intergrown lamellae of Ms and Pg.

Merriman $(2002,2005,2006)$ summarized the results of a systematic study carried out on the British Lower Paleozoic slate belts metamorphosed during Caledonian terrane amalgamation. He distinguished two contrasting phyllosilicate assemblages that were strongly related to different geotectonic settings. Former extensional basins are characterized by high thermal gradient, frequent volcanism, circulation of hydrothermal fluids, and mixed, Na-rich fluids that originated from the mixing of hydrothermal fluids and seawater. In this geotectonic setting the regional metamorphic assemblages of slates include $\mathrm{K}$ rich, intermediate $\mathrm{Na} / \mathrm{K}$ and Na-rich white micas, $\mathrm{Chl}$ and minor Prl. In regions affected by contact metamorphism and/or hydrothermal alteration, Corr, Rec and Prl also occur frequently. In convergent plate settings slates contain rather monotonous phyllosilicate assemblages that are dominated by phengite-rich $\mathrm{K}$ white mica and Chl, with sporadically minor amounts of Corr (in mafic-rich 
mudrocks). Na-rich micas are rare, as are Kln and Dick, whereas Nac, Prl and Rec are generally absent. Using also analogies from active hydrothermal systems along the Trans-Atlantic Geotraverse (TAG) and from the Izu-Bonin forearc basement characterized by Alt and Teagle (1998), Honnorez et al. (1998) and Alt et al. (1998), Merriman (2006) explained the phyllosilicate assemblages of extensional settings by circulation of alkali-enriched fluids with high $\mathrm{Na} / \mathrm{K}$ ratios, which were formed by mixing of hydrothermal fluids and seawater. In plateconvergent, accretionary settings the volcanic activity was very weak or absent, consequently such fluids were not available to produce the great variety of clay minerals. Although the works of Merriman $(2002,2005,2006)$ focused on the relationship between geotectonic settings (including volcanism and hydrothermal fluid circulation, mixing with seawater) and variability of low-T metamorphic phyllosilicate assemblages, the author explicitly stated that Naenriched mixed hydrothermal - seawater fluids with high $\mathrm{Na} / \mathrm{K}$ ratio unequivocally favor the formation of $\mathrm{Pg}$ and mixed K-Na-white micas.

\section{Materials and methods}

For the purposes outlined in the part "Introduction" a large data set was constructed from selected rock samples for which bulk rock major element analyses, XRPD modal analyses and illite Kübler index and chlorite "crystallinity" data have been available. On selected samples white mica EPMA, SEM, TEM and AEM analyses were partly available, partly done for the present study. These sample groups represent Alpine and Variscan low-T metamorphic terrains from the Swiss Central Alps, the Western Carpathians (Slovakia and Hungary), the Transdanubian Central Range (Pannonian Basin, Hungary) and the External Hellenides, Greece (see Table 2 for details of data sources and in them, for the details of analytical techniques used).

Thin sections of the Liassic black shale from locality A were observed on a JEOL 8600 Superprobe in order to map the elemental distributions. Both energy dispersive spectrometry (EDS) and wavelength dispersive spectrometry (WDS) (for $\mathrm{Na}, \mathrm{K}$, and $\mathrm{Fe}$ ) maps were generated at $\times 300$ magnification. At this magnification, the WDS images suffer from a slight intensity drop near the edges of the images due to Bragg angle defocusing. Maps were collected at pixel dimensions of $512 \times 400$ and dwell times ranging from 0.3 to $1 \mathrm{~s}$ making the longest map acquisition time over $57 \mathrm{~h}$.

Although equilibrium conditions at hand-specimen scale are generally reached only above ca. $300-350{ }^{\circ} \mathrm{C}$ (see e.g. Merriman and Peacor 1999), the authors tried to illustrate and understand the phase relations using pseudosections (quantitative phase diagrams) where the bulk composition of a rock is incorporated into the calculations. The PERPLEX software (Connolly 1990; Connolly and Petrini 2002) was used with an updated (2004) version of the internally-consistent thermodynamic data set of Holland and Powell (1998), and 
Dioctahedral mixed K-Na-micas and paragonite in diagenetic to low-temperature metamorphic terrains 289

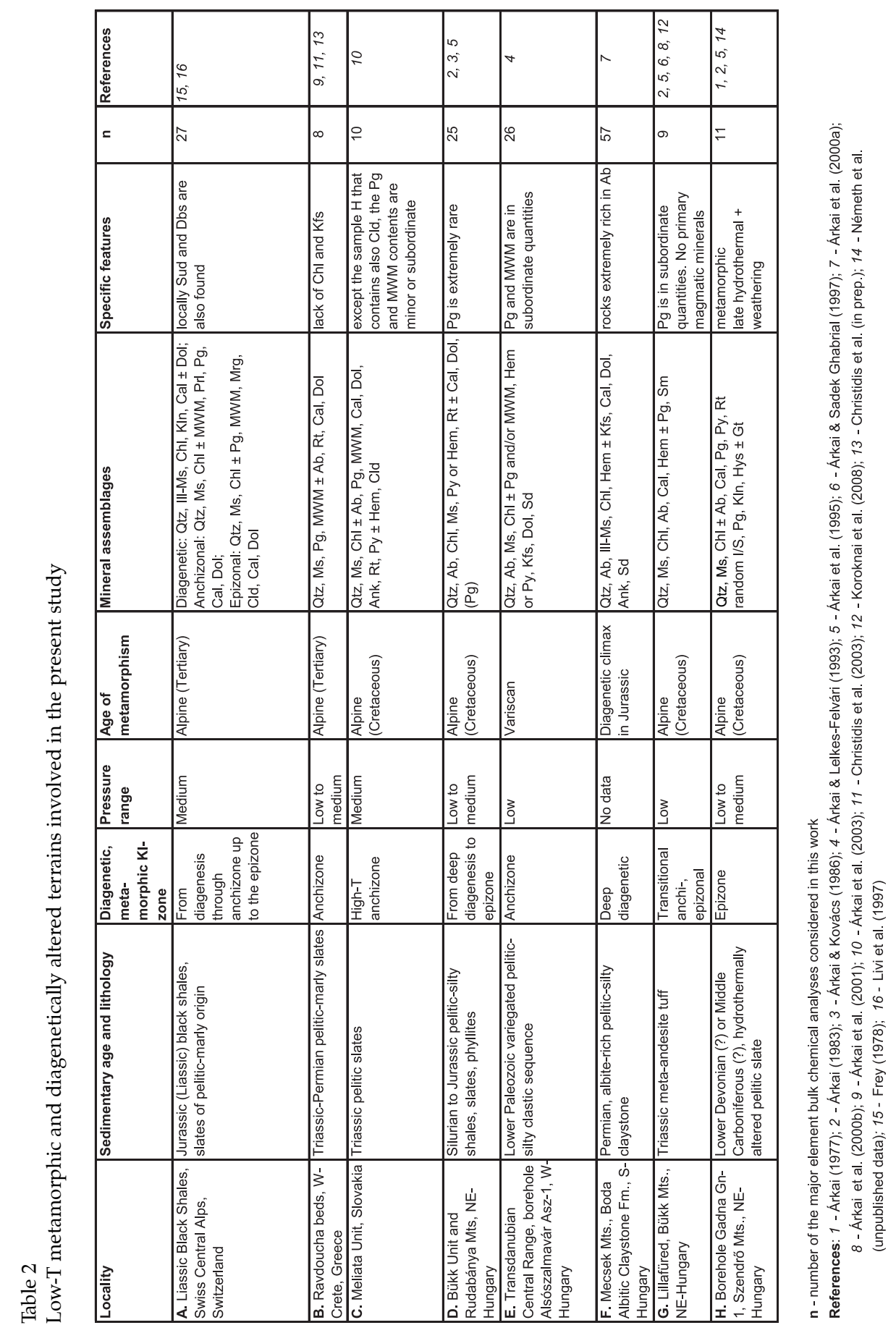

Central European Geology 51, 2008 


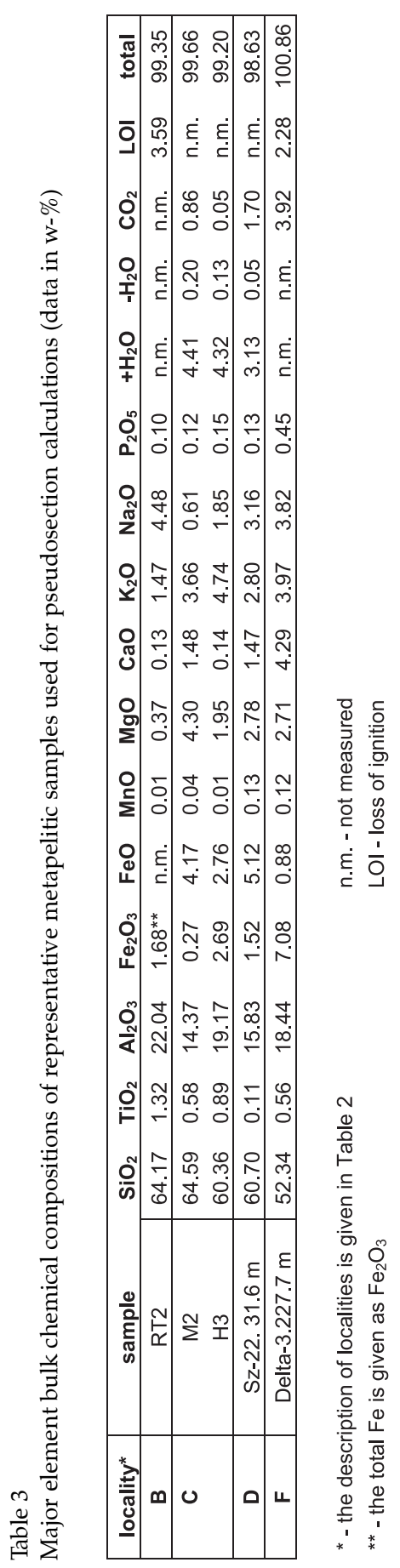

the THERMOCALC pseudosection modeling (Powell et al. 1998) was undertaken with the 3.25 version of the software and the internally consistent thermodynamic dataset 5.5 (August 2004 upgrade). All the constructed pseudosections are in the P-T range of $1-10 \mathrm{kbar}$ and $100-500{ }^{\circ} \mathrm{C}$ with quartz and $\mathrm{H}_{2} \mathrm{O}$ in excess. In the presented cases the two software packages yielded the same results (differences are in the order of a few degrees in temperature and a few hundred bars in pressure). Therefore, the results and diagrams obtained by the THERMOCALC method are presented here. The results below c. $300-350{ }^{\circ} \mathrm{C}$ should be handled with precaution, not only because of the lack of large-scale equilibrium conditions but also because of the well-known real natures of phyllosilicates, e.g. Ill-Ms (deficiency in interlayer cation content and presence of swelling mixed-layers) and Chl (interlayering with vermiculite and smectite at lower grades). Some of the samples (see Table 4) also contain minor ( $<5 \mathrm{wt}-\%) \mathrm{Cal}$ and one contains only minor amount of Dol. In spite of these, the calculations were carried out ignoring the $\mathrm{CO}_{2}$ and possibly $\mathrm{NH}_{4}$, etc., because judging from the modal compositions, the $\mathrm{XCO}_{2}$ might be rather low. Therefore the results are used only for rough orientation in the "Discussion". For Ms and Pg the solution model of Coggon and Holland (2002), for Chl the solution model of Holland et al. (1998) were used. Biotite was modeled using Powell and Holland (1999), for Cld the model of Holland and Powell (1998) was applied. Single end-member minerals with unit activities were: Jd, Gln and Qtz. For modeling the phase relations in the system NKFMASH $\quad\left(\mathrm{Na}_{2} \mathrm{O}-\mathrm{K}_{2} \mathrm{O}-\mathrm{FeO}-\mathrm{MgO}-\mathrm{Al}_{2} \mathrm{O}_{3}-\right.$ $\mathrm{SiO}_{2}-\mathrm{H}_{2} \mathrm{O}$ ) five samples were chosen (see Tables 3 and 4 and the section "Results") using the petrogenetic grid of Proyer (2003). 
Table 4

Mineral compositions of representative metapelitic samples used for pseudosection calculations

\begin{tabular}{|c|cccccccccc|}
\hline locality* & sample & Qtz & Ab & III-Ms & Pg & Chl & Cal & Dol & Hem & Py \\
\hline B & RT2 & X & tr & X & X & & & & & \\
\hline C & M2 & X & X & X & & X & X & & & \\
& H3 & X & X & X & X & X & & & & X \\
\hline D & Sz-22. $31.6 \mathrm{~m}$ & X & X & X & & X & X & & & X \\
\hline F & Delta-3.227.7 m & X & X & X & & X & X & X & X & \\
\hline
\end{tabular}

* - the description of localities is given in Table 2

$\operatorname{tr}-$ traces

\section{Results}

Bulk rock chemistry vs. occurrence of $\mathrm{Pg}$ and/or MWM

Bulk rock chemical data were plotted in the AKNa ternary diagram. Figure 1 shows the effects of isomorphic substitutions in white micas and alkali feldspars and the possible assemblages in the AKN system visualized by tie-lines and fields after Guidotti and Sassi (1976). In Fig. 1 EPMA data of K-white micas from localities $\mathrm{C}$ and $\mathrm{G}$ (see Table 2) are also plotted. Aluminoceladonitic and celadonitic substitutions in Ms result in shifts of projection points off the $\mathrm{Al}_{2} \mathrm{O}_{3}$ apex, and mixing of $\mathrm{K}$ and $\mathrm{Na}$ in the interlayer site of the Ms causes a drift towards Pg.

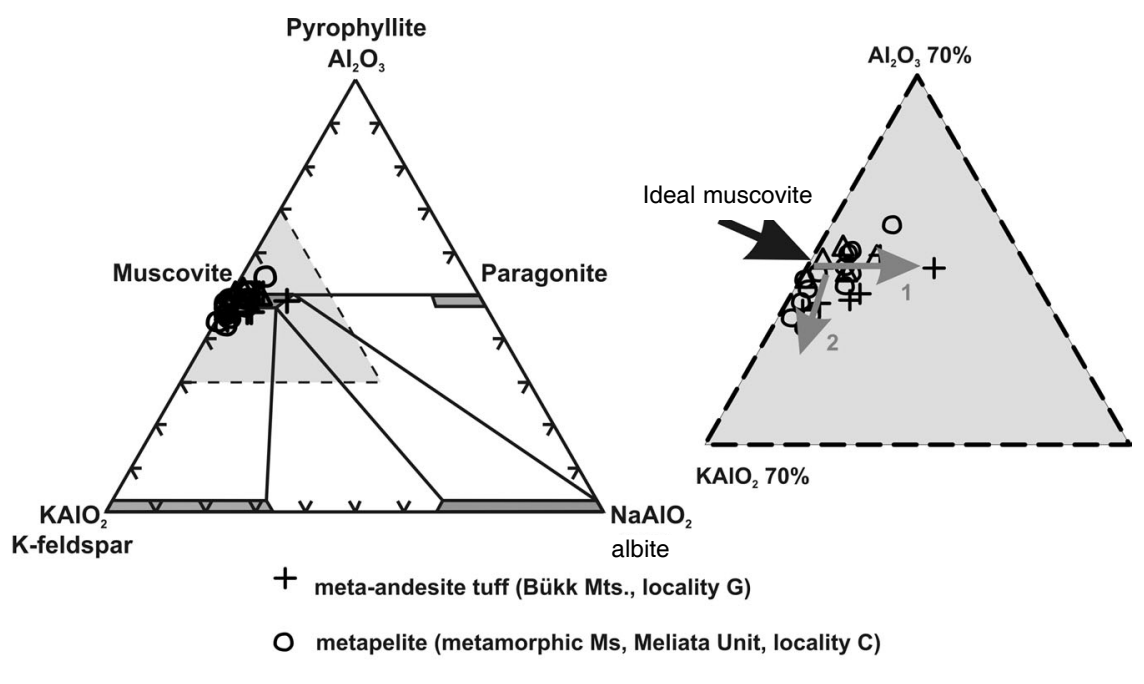

$\Delta$ metapelite (detrital Ms, Meliata Unit, locality C)

Fig. 1

The distribution of chemistries of K-white micas in the AKNa ternary. The solid solution fields of the minerals and tie-lines determining the low-T metamorphic mineral assemblages are displayed from Guidotti and Sassi (1976). In the blow-up (right triangle) arrow 1 shows the celadonitic, aluminoceladonitic, while arrow 2 the $\mathrm{Na} \rightarrow \mathrm{K}$ substitutions in Ms 
It must be stressed, however, that the extent of isomorphic $\mathrm{K} \leftrightarrow \mathrm{Na}$ substitution in $\mathrm{Ms}, \mathrm{Pg}, \mathrm{Kfs}$ and $\mathrm{Ab}$ is much more restricted at very low grades (temperatures) than they are given in Fig 1 (see Guidotti and Sassi 1976; 1998). Therefore, for simplicity only the projections of the ideal end members are given in the following diagrams.

Figure 2 plots all bulk rock chemical data from the regions (localities listed in Table 2). The data points for rocks that contain Pg and/or mixed K-Na-white mica in addition to Ms (henceforth "Pg-bearing rocks") and data points for rocks that contain only Ms as dioctahedral white mica ("Pg-free rocks") scatter over wide ranges, and overlap each other. However, Pg-bearing samples concentrate nearer to the $\mathrm{Al}_{2} \mathrm{O}_{3}$ corner than those of the Pg-free rocks (compare Figs $2 \mathrm{a}$ and $2 \mathrm{c}$ ).

As it is used in Fig. 2, the AKNa ternary assumes a rather simple system consisting of pure (hydrous or anhydrous) aluminosilicates, K- and Na-white

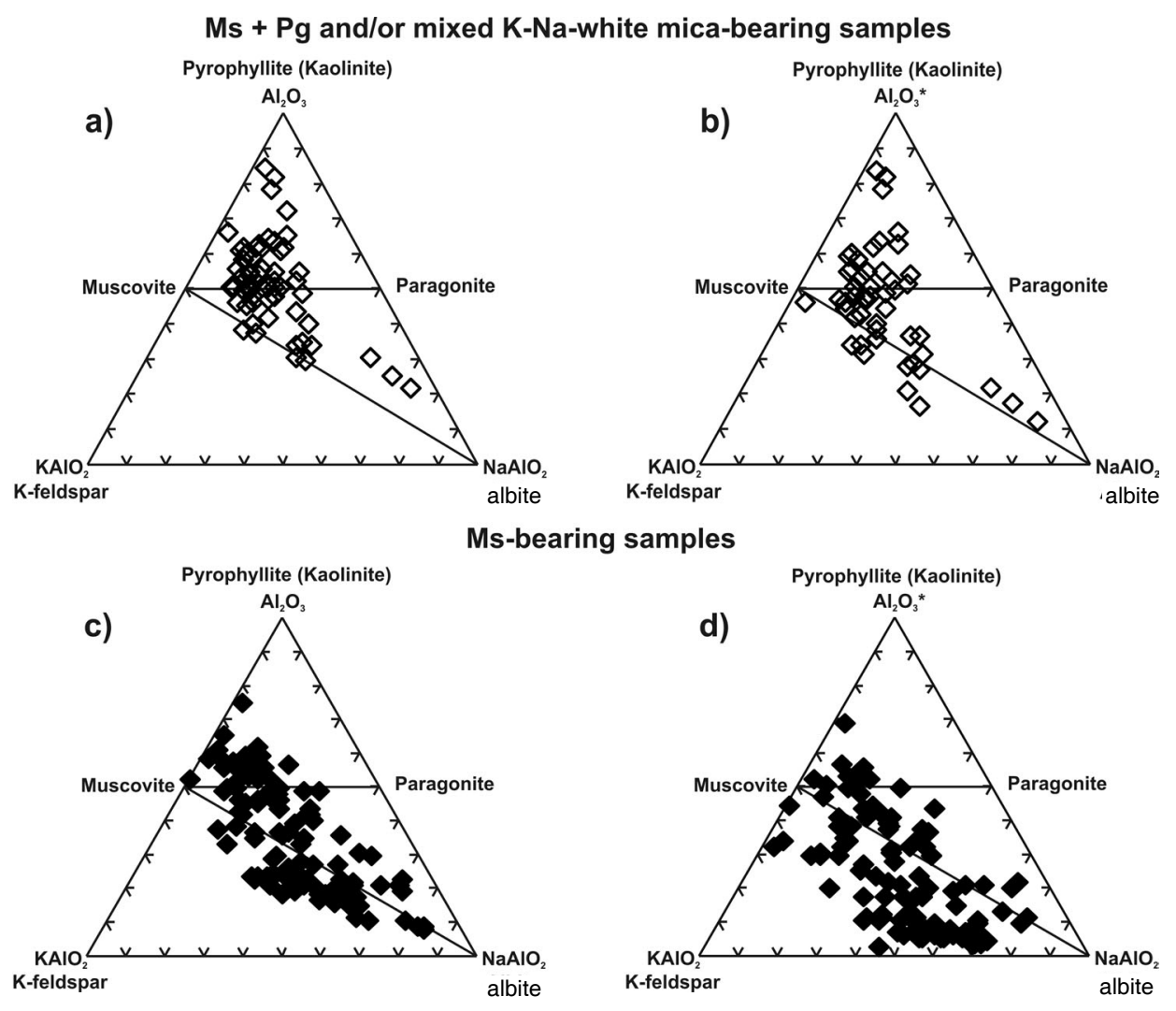

Fig. 2

Distributions of bulk rock chemical analyses of all samples used in the present study in the AKNa ternary diagram (data in mole $\%$ ). $\mathrm{Al}_{2} \mathrm{O}_{3}{ }^{*}$, i.e. the corrected alumina content represents the alumina related to feldspars, white micas and/or pure aluminosilicates. (For detailed explanation see the text) 
micas and alkali feldspars ( $\mathrm{SiO}_{2}$ and $\mathrm{H}_{2} \mathrm{O}$ are in excess). The presence of other Albearing ( $\mathrm{Fe}$ - and $\mathrm{Mg}$-containing) phases such as $\mathrm{Chl}$ and $\mathrm{Cld}$, etc. in a sample will cause a remarkable shift of its projection point towards the $\mathrm{Al}_{2} \mathrm{O}_{3}$ corner Therefore, where the plotted samples also contain chlorite (or very rarely, chloritoid), the $\mathrm{Al}_{2} \mathrm{O}_{3}$ values of the $\mathrm{AKNa}$ ternary were corrected as follows to obtain $\mathrm{Al}_{2} \mathrm{O}_{3}{ }^{*}$ values (Fig. $2 \mathrm{~b}$ and $2 \mathrm{~d}$ ). In cases when XRPD-calculated modal composition of rocks and also, actual chemical composition of Chl determined by EPMA or ATEM were available, the composition of Chl weighted with the amount of Chl in the rocks was subtracted from the bulk rock chemical composition. The remaining chemical composition modified in this way served as basis for calculating the $\mathrm{Al}_{2} \mathrm{O}_{3}{ }^{*}$ mole amount that is not related to chlorite (a similar procedure was applied for samples with Cld).

In most cases, however, only a rough correction of the $\mathrm{Al}_{2} \mathrm{O}_{3}$ could be done. Surveying many literature data it can be concluded that most of the chlorites in anchizonal and epizonal metaclastic rocks of normal marine origin are ripidolite or brunsvigite (using the nomenclature of Foster 1962). According to Laird (1988, Fig. 2 in p. 410), the $\mathrm{Al}_{\mathrm{Chl}}^{\mathrm{t}} /\left(\mathrm{Al}_{\mathrm{Chl}}^{\mathrm{t}}+\mathrm{Fe}^{2+}+\mathrm{Mg}\right)$ ratios of the overwhelming majority of chlorites analyzed from metamorphic rocks fall between ca. 0.3 and 0.4, chlorites from metapelitic rocks being more aluminous than those from other (magmatic or sedimentary) lithologies. For samples in the present paper without quantitative modal composition and chlorite mineral chemistry data, an average value of $\mathrm{Al}_{\mathrm{Chl}}^{\mathrm{t}} /\left(\mathrm{Al}^{\mathrm{t}} \mathrm{Chl}+\mathrm{Fe}^{2+}+\mathrm{Mg}\right)=0.385$ was used for metapelitic chlorites estimated from Fig. 2 of Laird (1988, p. 410). By rearranging this equation, a rough estimate of $\mathrm{Al}_{\mathrm{Chl}}^{\mathrm{t}}=0.63^{*}\left(\mathrm{Fe}^{2+}+\mathrm{Mg}\right)$ can be obtained. In this way the $\mathrm{Al}^{*}$ (the remaining $\mathrm{Al}$ of the rock that does not relate to chlorite) can be obtained by the equation $\mathrm{Al}^{*}=\mathrm{Al}_{\text {rock }}^{\mathrm{t}}-\left[\left(\mathrm{Fe}^{2+}+\mathrm{Mg}\right)_{\text {rock }} / 1.6\right]$. It must be emphasized, however, that this correction produces only rather rough estimates and may be valid only for rocks in which chlorite is the only $\left(\mathrm{Fe}^{2+}+\mathrm{Mg}\right)$-bearing phase. Consequently, $\mathrm{Dol}$, Ank and/or Sd must be taken into account, or rocks with such phases should be excluded. The aluminoceladonitic, celadonitic substitutions in Ms, as well as the $\mathrm{Fe}^{2+}$ content related to pyrite or other accessory minerals may be taken also into account. Figure 3 shows the differences in the position of projection points in the AKNa ternary obtained by using the various correction methods outlined above. There are only minor, insignificant differences between the points corrected using the generalized, average chlorite composition and those corrected by the actual XRPD-calculated modal and EPMA Chl chemical data. Even in relatively celadonite-rich $\mathrm{K}$-white micas (e.g. those from localities $\mathrm{C}$ and $\mathrm{G})$ the effects of these substitutions and phases to the bulk rock $\left(\mathrm{Fe}^{2+}+\mathrm{Mg}\right)$ budget were subordinate, causing only minor shifts in the projection. Notwithstanding, these omissions may result in a small-scale underestimation of the $\mathrm{Al}^{*}$ (and $\mathrm{Al}_{2} \mathrm{O}_{3}{ }^{*}$ ) data.

The AKNa plots of bulk rock chemistries using these corrected $\mathrm{Al}_{2} \mathrm{O}_{3}{ }^{*}$ data are shown in Fig. $2 \mathrm{~b}$ and $2 \mathrm{~d}$, giving more reliable distributions than Fig. $2 \mathrm{a}$ and $2 \mathrm{c}$, 


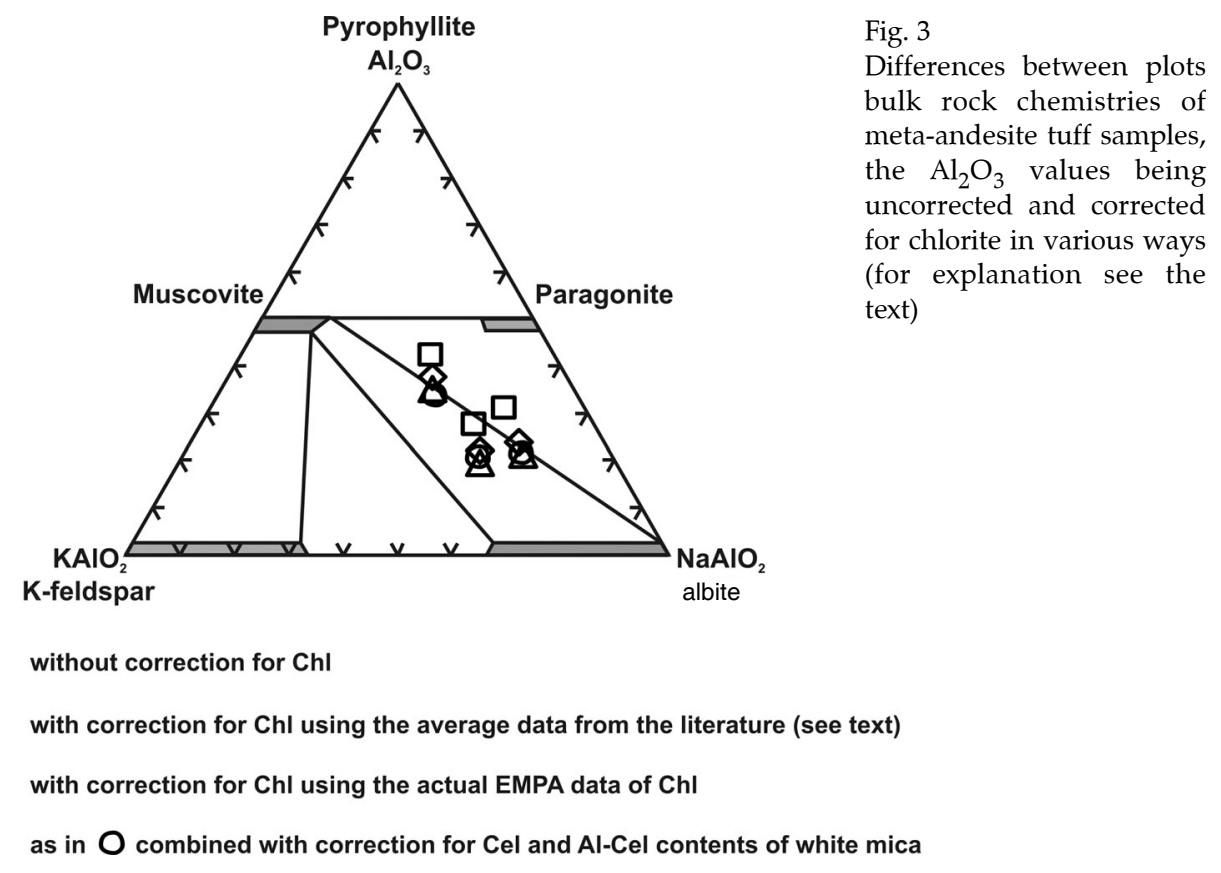

therefore in the followings only the results obtained using the corrected $\mathrm{Al}_{2} \mathrm{O}_{3}$ * data will be presented and discussed. Most of the Pg-bearing rocks are concentrated along and around the Ms-Pg tie-line and in the Ms-Pg-Prl $(\mathrm{Kln})$ and Ms-Pg-Ab fields, whereas those of the Pg-free rocks show greater scatter along and around the Ms- $\mathrm{Ab}$ tie, with the majority in the Ms-Ab-Kfs field, although these rock samples do not contain Kfs as proved by systematic XRPD studies. There are several explanations for solving this apparent contradiction. Thus, a) either the $\mathrm{Al}_{2} \mathrm{O}_{3}$ contents of chlorites were overestimated during the correction and/or $\mathrm{b}$ ) the $\mathrm{K}$ content of the alkali-feldspars (especially of larger-grained, detrital alkali feldspars that did not take part in the diagenetic and low- $\mathrm{T}$ metamorphic reactions) cause shifts towards the $\mathrm{KAlO}_{2}$ (see also Fig. 3, where the $\mathrm{Ms}-\mathrm{Ab}$ tie is not a single line but a rather wide zone because of the $\mathrm{Na}, \mathrm{K}$ substitution in feldspar). In spite of these uncertainties of the correction, the averages of the two populations are strongly different - the $\mathrm{Al} / \mathrm{K}$ and $\mathrm{Al} / \mathrm{Na}$ ratios of the Pg-bearing rocks being larger than those of the Pg-free rocks.

The Liassic black shale containing Pg and/or MWM (locality A) proves to be extremely Al-rich in general (Fig. 4A). There are no systematic differences in the $\mathrm{K} / \mathrm{Al}^{*}$ and $\mathrm{Na} / \mathrm{Al}^{*}$ ratios as a function of grade. Although the Prl- or Cld-bearing

Fig. $4 \rightarrow$

AKNa plots of bulk chemical analyses from localities $\mathrm{A}$ to $\mathrm{H}$ (for characterization of the localities see Table 2). Further explanations to Fig. 4C (Meliata unit): M: Meliata, H: Hačava, Rb: Rožňavské Bystre and Dz: Drkovce 
Dioctahedral mixed K-Na-micas and paragonite in diagenetic to low-temperature metamorphic terrains 295
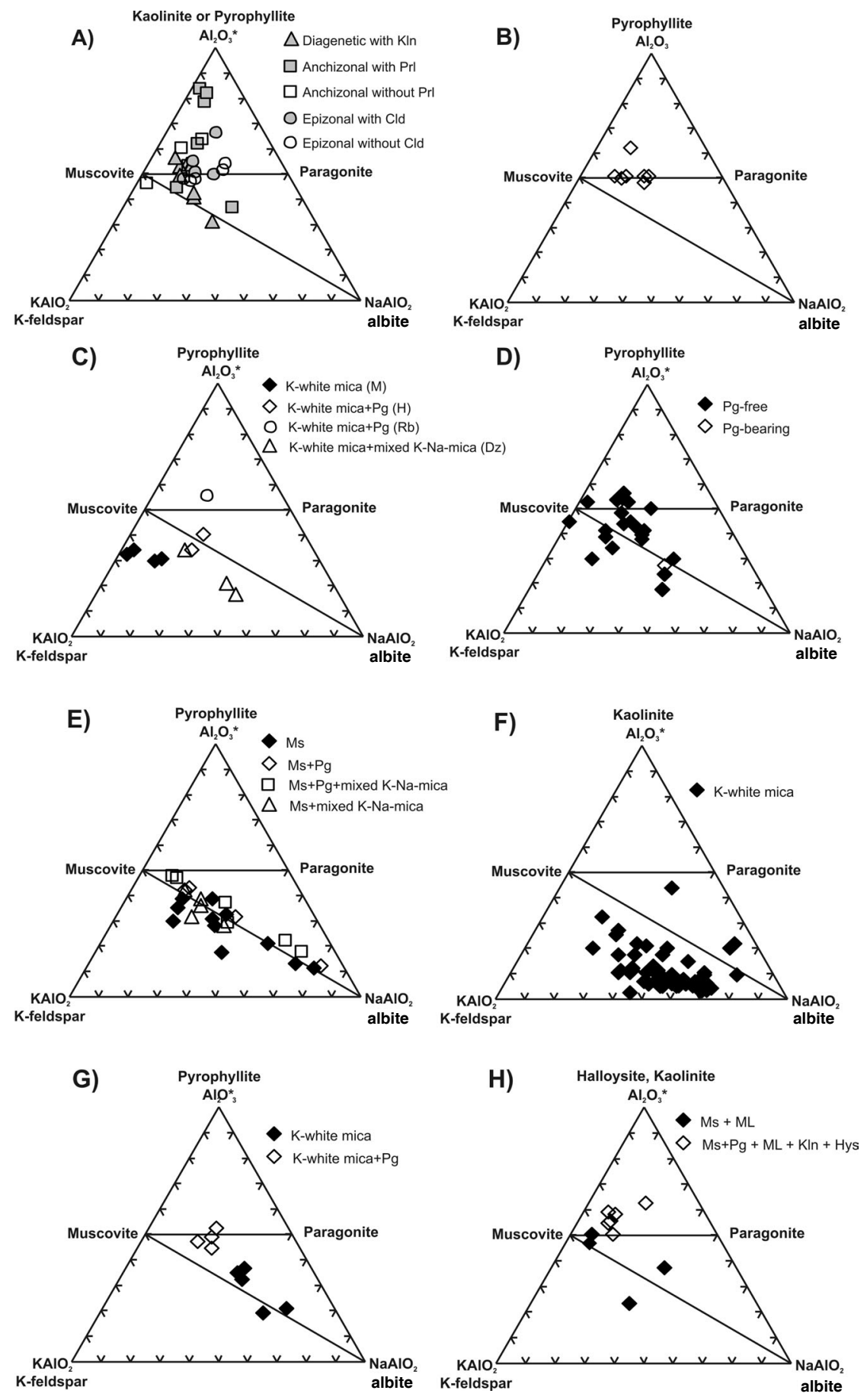

Central European Geology 51, 2008 
samples are the richest in $\mathrm{Al}^{*}$, there are considerable overlaps between these and the Prl- or Cld-free samples. The Kln-bearing diagenetic samples do not prove to be rich in $\mathrm{Al}^{*}$. In general, the majority of the black shale samples plots in the $\operatorname{Prl}(\mathrm{Kln})-\mathrm{Ms}-\mathrm{Pg}$ field. However, a considerable number of the analyzed rocks plot along the Ms-Pg tie-line, in the Ms-Pg-Ab field and along the Ms-Ab tie-line as well.

The Cretan metapelitic to marly rocks (locality B) often contain Pg and MWM. The bulk chemistries of these rocks plot along the Ms-Pg tie (Fig. 4B). These rocks do not contain chlorite or other Al-bearing Fe-Mg-phases, so no correction for $\mathrm{Al}$ was needed.

The Triassic fine-grained metaclastic rocks of locality $\mathrm{C}$ formed in an accretionary wedge-like setting. Their Pg and MWM contents are, except for the sample Rožňavské Bystre (Rb), minor. Their plots (Fig. 4C) show no systematic scatter except the Rožňavské Bystre sample, which in addition to considerable amount of Pg also contains Cld.

As Fig. 4D shows, the distributions of corrected bulk chemical ratios from the locality D vary rather strongly and irregularly. In these rocks Pg is extremely rare.

A variegated Lower Paleozoic metaclastic sequence (locality E) often contains discrete Pg and/or MWM (both in minor quantities). Their bulk chemical molar ratios plot along and around the Ms-Ab tie-line (Fig. 4E). Only a small shift of the Pg-bearing rocks towards the $\mathrm{Al}_{2} \mathrm{O}_{3}{ }^{*}$ corner can be seen as compared to the Pgfree rocks.

In order to check the phase relations in an especially Na-rich lithotype, the thick Upper Permian Boda Albitic Claystone Formation (locality F) selected as a possible repository for high-level nuclear waste was studied. This formation was deposited in a shallow-water lacustrine environment, under semi-arid to arid climatic and highly alkaline (Na-rich) and oxidative hydrological conditions. Illite Kübler index and chlorite "crystallinity" indices indicate deep diagenetic conditions. The rocks are characterized by extremely high, authigenic $\mathrm{Ab}$, low Qtz, high Hem and moderate carbonate contents in addition to Ill-Ms and Chl. The $\mathrm{Ab}$ content varies between ca. 10 and $60 \mathrm{wt} \%$, the average $\mathrm{Na}_{2} \mathrm{O}$ content is $4.04 \mathrm{wt} \%$ (median $=3.97$; mode $=4.80$ and $\mathrm{s}=1.21 \mathrm{wt} \%, \mathrm{n}=57$ ). The $\mathrm{Al}_{2} \mathrm{O}_{3}$ content varies in a relatively narrow range from 10.30 to $19.83 \mathrm{w} \%$ (mean value $=16.65 \mathrm{wt} \%)$. These Na-rich rocks do not contain either Pg or its precursor phases (MWM, brammallite or Na-smectite). Theoretically, these rock samples should be plotted along the Ms-Ab tie. However, as can be seen in Fig. 4F, the points are displaced within the Ms-Ab-Kfs field with very few exceptions, after correcting for chlorite, although no Kfs was detected in these samples by XRPD either

In order to avoid the interference from inherited (detrital) mineral grains that are practically always present in fine-grained metaclastic rocks, the meta-andesite tuff from locality $\mathrm{G}$ was also considered. The studied samples were collected from a small outcrop representing an apparently homogeneous mass of the typical 
rock type. This rock originated from fine-grained pyroclastics completely altered during transitional anchi-, epizonal regional metamorphism. Because of alteration, primary magmatic mineral phases are lacking in these rocks displaying strong slaty cleavage and banding. Frequent feldspar (most probably plagioclase) phenocrysts or phenoclasts are fully albitized, and the sporadically occurring former mafic phenocrysts (pyroxene or amphibole?) are completely replaced by a fine-grained mixture of $\mathrm{Chl}$ and opaque minerals. The magmatic groundmass is also fully recrystallized to a fine-grained mixture of metamorphic phases. The local appearance of Pg is worth closer inspection, because this is the first recorded occurrence of $\mathrm{Pg}$ in the Bükk Mountains. There is a significant decrease in the amounts of $\mathrm{Ab}$ in those samples which contain Pg. Paragonite is present in those samples in which the $\mathrm{Na} / \mathrm{Al}^{*}$ ratio is systematically lower than those of the paragonite-free samples. This difference is closely related to the mineral chemical differences between $\mathrm{Ab}$ and $\mathrm{Pg}$ (see Fig. 1). After correcting for $\mathrm{Chl}$, the projection points of bulk chemistries of the Pg-bearing samples are very close to the Ms-Pg tie, while those of the Pg-free samples scatter around the Ms$\mathrm{Ab}$ tie (Fig. 4G).

In locality $\mathrm{H}$ the effects of low-T hydrothermal fluids on an epizonal slate sequence are demonstrated. Here the metamorphic mineral assemblages contain Qtz, Ms, Chl $\pm \mathrm{Ab}$, Cal, Pg, Py and Rt, while the late hydrothermal activity produced randomly interstratified I/S (through out the whole profile), considerable amounts of discrete $\mathrm{Pg}$, Kln, frequent halloysite (Hys) \pm Gt in the upper part of the borehole (down to ca. $45 \mathrm{~m}$ ). It is notable that rare, small Narich paragonitic domains were found in Ms flakes of the lower part of the profile by EPMA. The amount of this Pg is small, because no XRPD evidence could be found for the whole rock or the $<2 \mu \mathrm{m}$ grain-size fraction samples. Figure 5 displays the variations of chemical composition and atomic ratios in the profile of the borehole. Major element contents show strong fluctuations that may be attributed partly to the original heterogeneity of the clayey-silty series and mostly to the effects of hydrothermal activity that was intense in the upper and moderate to weak in the lower parts of the sequence. Note the opposite changes in $\mathrm{SiO}_{2}$ and $\mathrm{Al}_{2} \mathrm{O}_{3}$ contents and the relatively high $\mathrm{Al}_{2} \mathrm{O}_{3}$ content especially in the Hys- and Kln-bearing upper part. The $\mathrm{Fe}_{2} \mathrm{O}_{3}$ content decreases, the $\mathrm{FeO}$ content increases downwards, reflecting oxidation in the late stage of hydrothermal activity or near-surface weathering. Only very small-scale fluctuations in $\mathrm{Na}_{2} \mathrm{O}$, and by contrast large fluctuations in $\mathrm{K}_{2} \mathrm{O}$, can be seen. Neither the $\mathrm{Al} /(\mathrm{Al}+\mathrm{Si})$ nor the $\mathrm{K} /(\mathrm{K}+\mathrm{Al})$ and $\mathrm{Na} /(\mathrm{Na}+\mathrm{Al})$ atomic ratios show systematic differences between the Pg- (and Kln and/or Hys-) bearing upper and the practically Pg-free lower parts.

By contrast, if the corrected $\mathrm{Al}^{*}$ values are used, the $\mathrm{K} /\left(\mathrm{K}+\mathrm{Al}^{*}\right)$ and especially the $\mathrm{Na} /\left(\mathrm{Na}+\mathrm{Al}^{*}\right)$ ratios are higher in the Pg-free than in the Pg-bearing samples. These features are reflected also in the AKNa plot (Fig. 4H). After correcting the original molar fractions for chlorite, the Pg-free samples widely scatter along the 


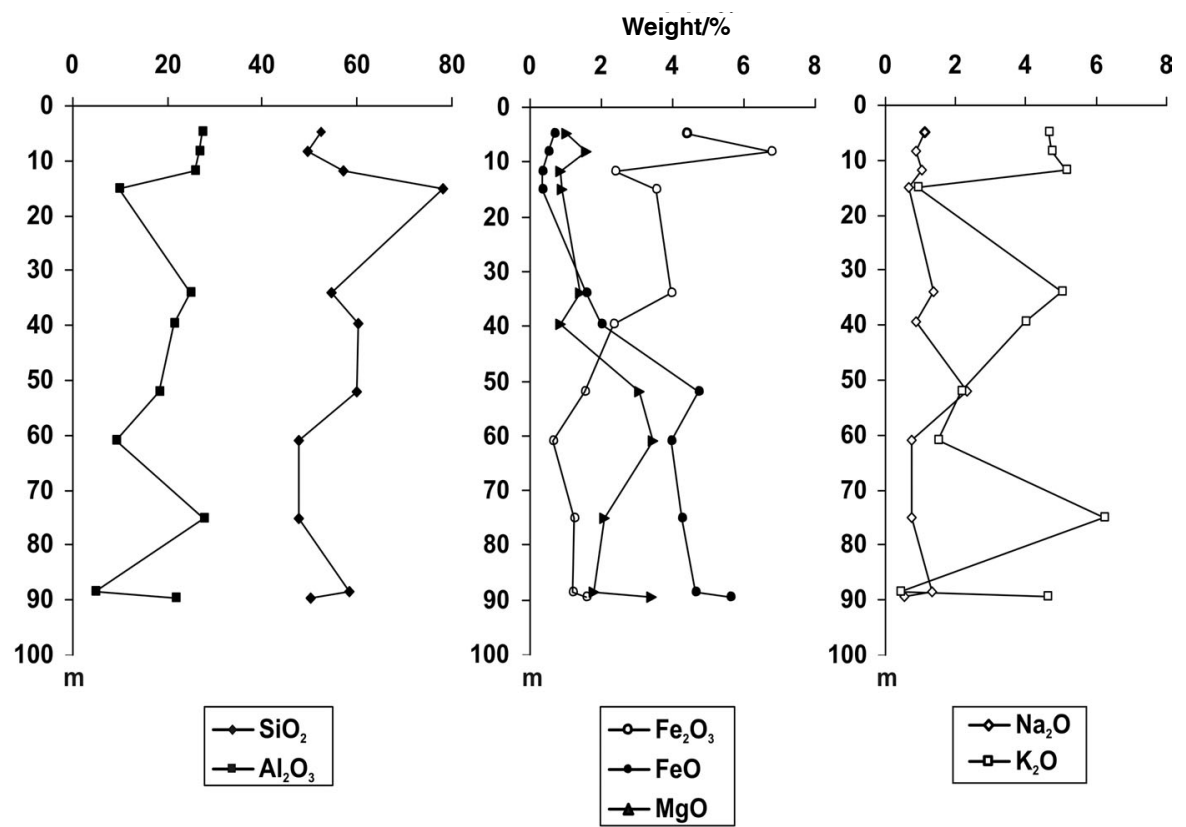

$\begin{array}{lllllll}0 & 0.1 & 0.2 & 0.3 & 0.4 & 0.5\end{array}$

Atomic ratio
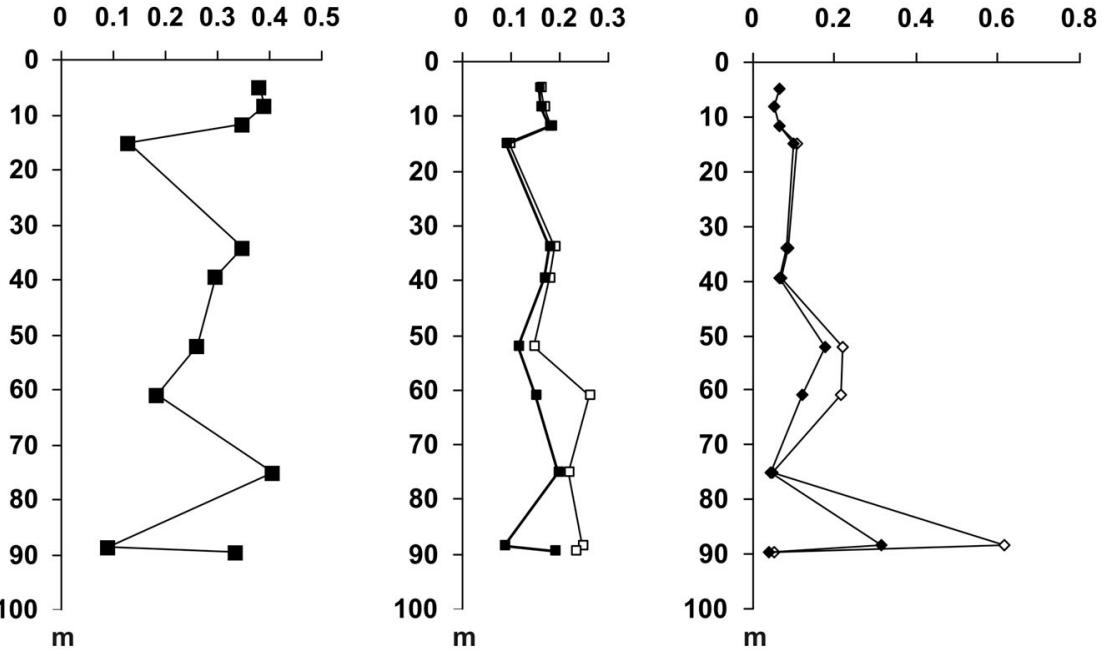

$\rightarrow-\mathrm{Al} /(\mathrm{Al}+\mathrm{Si})$
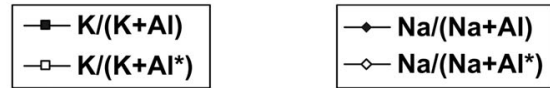

Fig. 5

Changes in bulk rock major element compositions (w-\%) and in some atomic ratios in the section of borehole Gadna Gn-1, Szendrő Mts, NE-Hungary (locality H) 
Ms-Ab tie and are partly located very near to Ms, while the Pg (and also Hys and $\mathrm{Kln}$ ) bearing samples in the Hys/Kln-Ms-Pg field, near the Ms-Pg tie.

\section{P-T stability field of Pg-bearing assemblages based on thermodynamic calculations}

Representative metapelite samples with bulk rock chemistries and mineral compositions given in Tables 3 and 4 were selected for modeling phase relations in the NKFMASH system. The concept for selection was to study metapelite samples that do or do not contain $\mathrm{Pg}$ and/or $\mathrm{Ab}$ in addition to the 'normal' low- $\mathrm{T}$ metamorphic assemblages of Qtz, Ms and Chl. These samples are characterized by various $\mathrm{Al}_{2} \mathrm{O}_{3}$ contents and $\mathrm{Na} /\left(\mathrm{Na}+\mathrm{Al}^{*}\right)$ and $\mathrm{K} /\left(\mathrm{K}+\mathrm{Al}^{*}\right)$ ratios. The pseudosections of these samples are shown in Fig. 6 and are described below.

Locality B, sample RT-2. According to XRPD investigations this sample has equal amounts of Ms, Pg and Qtz (ca. 30\%), and accessory phases like Rt and graphite. $\mathrm{Ab}$ - and/or Pg-bearing fields occupy almost the entire P-T field with Chl-Ms-Pg covering the largest one (Qtz and $\mathrm{H}_{2} \mathrm{O}$ are in excess in the whole P-T area). Cld joins in at pressures between 7 and $8 \mathrm{kbar}$ to form Chl-Cld-Ms-Pg, while Bt would form only at the high-T part, outside the estimated P-T field of the given sample. Ab becomes part of the assemblage Chl-Ms-Pg along a shallow positive slope. The $x(\mathrm{Chl})$ values are generally constant, while $x(\mathrm{Ms})$ is increasing with increasing $\mathrm{P}$ and $\mathrm{T}$. (The $\mathrm{x}(\mathrm{i})$ value is $\mathrm{Fe} /(\mathrm{Fe}+\mathrm{Mg}$ ) in phase (i), na(Ms) is $\mathrm{Na} /(\mathrm{Na}+\mathrm{K})$ in Ms.) With increasing T, Pg breaks down along a steeper, but still positive slope. The observed assemblage of Chl-Ms-Pg-Ab is stable from ca. $250{ }^{\circ} \mathrm{C}$ and $1 \mathrm{kbar}$ to $450{ }^{\circ} \mathrm{C}$ and $4.5 \mathrm{kbar}$.

Locality $\mathrm{C}$, sample $\mathrm{H}-3$. This sample contains both $\mathrm{Pg}$ and $\mathrm{Ab}$ in low modal content with Chl, Ms and Qtz as major phases. The relatively Na-rich nature of the protolith is highlighted in the pseudosection as all fields have a stable Nabearing phase. At high-P Jd and Gln are also stable with Pg. Paragonite and Ab coexist in a wide P-T field up to ca. $450{ }^{\circ} \mathrm{C}$ at high P where, with increasing T, Pg breaks down. The $\mathrm{Bt}$-in line is at ca. $350^{\circ} \mathrm{C}$ at $1 \mathrm{kbar}$ and has a very steep positive slope. The measured $x(\mathrm{Chl})$ value is 0.59 . The calculated values are between 0.45 and 0.70 in the whole P-T window considered. The Bt-in line has a constant $x(\mathrm{Chl})$ of 0.45 , while the Pg-in line has $0.45-0.48$. The $x(\mathrm{Ms})$ is $0.51-0.56$ for the Gln-in line. The largest compositional range was calculated for the Jd-in line. With decreasing $\mathrm{P}$ the $\mathrm{x}(\mathrm{Ms})$ values increase from 0.55 to 0.70 . The na(Ms) is $0.01-0.02$ for the Gln-in line and under 0.01 for Jd-in. We must emphasize that these reaction assemblages are Pg-bearing. The $\mathrm{Bt}$-in and Pg-in lines are richer in na(Ms) with $0.04-0.12$ and $0.03-0.12$, respectively. The na(Ms) value is increasing with increasing $P$, then decreases when Pg becomes part of the assemblage.

Locality $C$, sample $M-2$. This sample contains Qtz, Ms and Chl in nearly equal amount with a low modal content of $\mathrm{Ab}$ and minor $\mathrm{Cal}$. The pseudosection shows that the Chl-Ms-Ab assemblage is stable between ca. 100 and $350{ }^{\circ} \mathrm{C}$ at low pressures. Biotite joins this assemblage at higher $\mathrm{T}$ (over ca. $300{ }^{\circ} \mathrm{C}$ ), while Pg- 

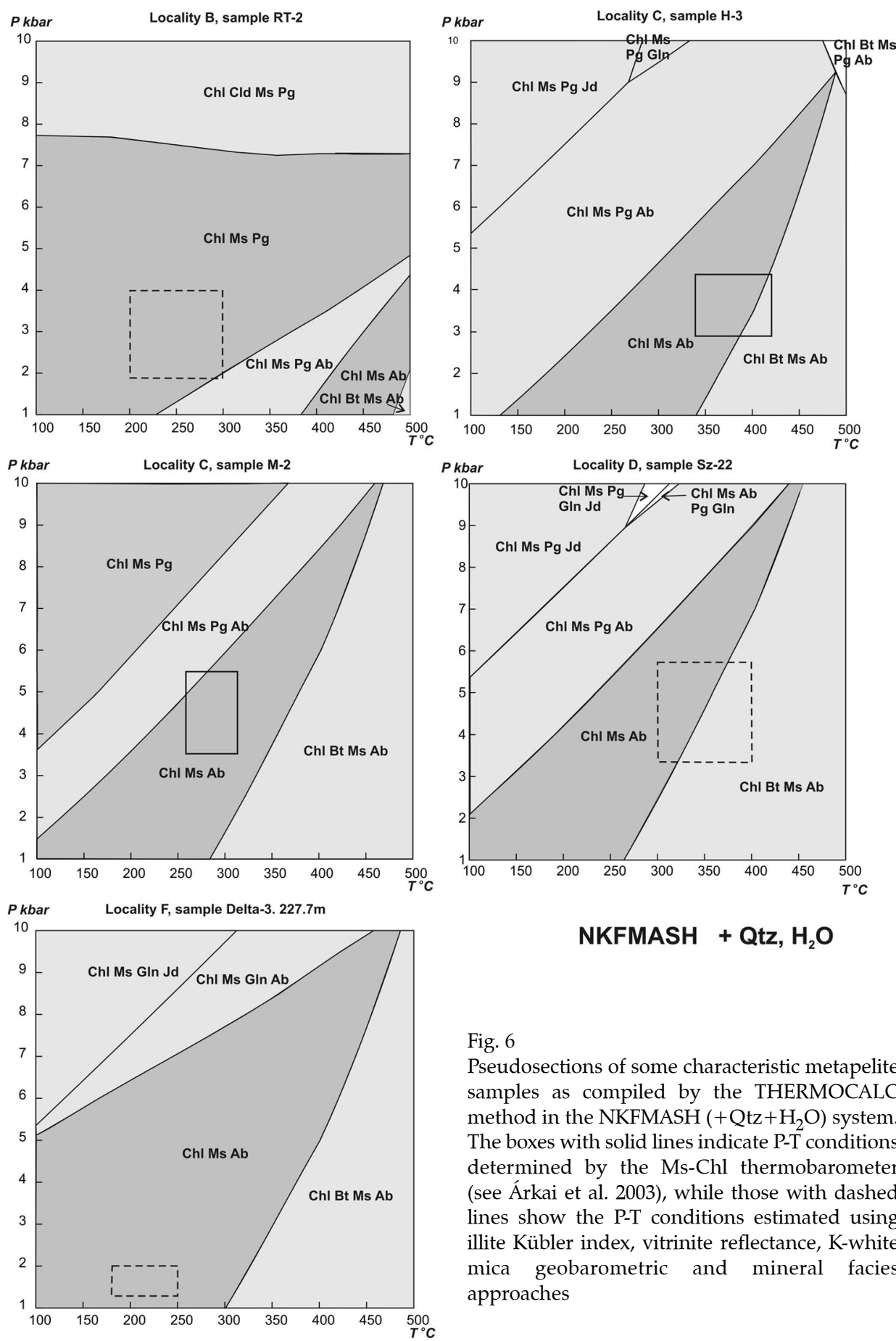

\section{NKFMASH + Qtz, $\mathrm{H}_{2} \mathrm{O}$}

Fig. 6

Pseudosections of some characteristic metapelite samples as compiled by the THERMOCALC method in the NKFMASH $\left(+\mathrm{Qtz}+\mathrm{H}_{2} \mathrm{O}\right)$ system. The boxes with solid lines indicate P-T conditions determined by the Ms-Chl thermobarometer (see Árkai et al. 2003), while those with dashed lines show the P-T conditions estimated using illite Kübler index, vitrinite reflectance, K-white mica geobarometric and mineral facies approaches 
bearing fields occur at higher P. With increasing $\mathrm{P}$, coexisting $\mathrm{Ab}$ and $\mathrm{Pg}$ with $\mathrm{Chl}$ and Ms appear in a relatively narrow field between $100{ }^{\circ} \mathrm{C}$ at $1.5 \mathrm{kbar}$ and $450{ }^{\circ} \mathrm{C}$ at 10 kbar. Paragonite is unstable over $450{ }^{\circ} \mathrm{C}$ in the studied $\mathrm{P}$ range. The $\mathrm{x}(\mathrm{Chl})$ value is $0.36-0.38$ at the Pg-in line with the higher values at lower $\mathrm{P}$, while it is ca. 0.36 at the Bt-in line. The $x(\mathrm{Ms})$ is between 0.11 and 0.31 and na(Ms) is $0.01-0.08$. Both values increase with increasing pressure. Árkai et al. (2003) measured $x(\mathrm{Chl})$ of 0.46 in sample M-2 which is somewhat higher than the calculated ones. Measured $x(\mathrm{Ms})$ is 0.47 which is quite different from the modeling data, while the $\mathrm{na}(\mathrm{Ms})$ value is 0.02 , falling in the range of the calculated ones.

Locality D, sample Sz-22. $31.6 \mathrm{~m}$. The stable assemblage of the sample is Chl, Ms, $\mathrm{Ab}$ and Qtz with some accessory phases. The calculated pseudosection shows that this assemblage is stable from ca. $100{ }^{\circ} \mathrm{C}$ to $400{ }^{\circ} \mathrm{C}$ at low and medium pressures. At higher temperatures $\mathrm{Bt}$ forms, while with a pressure increase $\mathrm{Pg}$ joins in. At even higher pressure Jd and Gln replace Ab. The Pg-out reaction line has a moderate positive slope with generally constant mineral chemical parameters.

Locality F, sample Delta-3. $227.7 \mathrm{~m}$. The sample originates from an Ab-rich claystone. It contains $\mathrm{Chl}, \mathrm{Ms}, \mathrm{Qtz}$ and $\mathrm{Ab}$. No Pg was found in the entire formation. P-T pseudosection from the sample supports this observation with Chl-Ms-Ab covering the largest part of the P-T field. Bt appears at ca. $300-450{ }^{\circ} \mathrm{C}$, at higher temperatures with increasing pressure. Gln is present at pressures above $5 \mathrm{kbar}$, while Jd replaces $\mathrm{Ab}$ at higher pressures. The $\mathrm{x}(\mathrm{Chl})$ and $\mathrm{x}(\mathrm{Ms})$ values are low (0.16-0.17 for $\mathrm{Chl}, 0.10-0.13$ for $\mathrm{Ms})$ reflecting the $\mathrm{Fe}^{2+}$-poor nature of the rock (Table 3). The Pg content of Ms [na(Ms)] values is also low (0.04-0.07).

\section{Textural analysis of $P g$ formation}

X-ray maps were gathered for diagenetic and anchizonal grade samples from the Liassic Black shale (group A) in order to determine the spatial distribution of Na-rich phases in Al-rich shale. The work of Livi et al. (1997) presented a clear progression of illite/muscovite compositions with grade. Here we present data that shed light on the notion of local equilibrium assumed to be operating at low temperatures.

Diagenetic grade. X-ray maps for several elements are presented in Fig. 7 for a sample from Berlingen (B7) in the Molasse Basin in Central Switzerland (Frey 1978). The phases present in this sample were identified through backscattered electron (BSE) imaging, EDS analyses and X-ray map intensities. The important phases for this study are $\mathrm{Ab}, \mathrm{Kln}, \mathrm{Kfs}$ and I/S. Two feldspars are present in the maps, $\mathrm{Ab}$ in the center shown by the Na map and Kfs on the bottom left in the K map. There are also a few tiny particles of $\mathrm{Ab}$ and Kfs dispersed throughout the mapped area. In contact with the larger feldspars are Kln and I/S. There is no evidence of the formation of mixed white micas or brammallite (Brm) at the Kln$\mathrm{Ab}$ contacts in this or other diagenetic samples, but there are isolated 


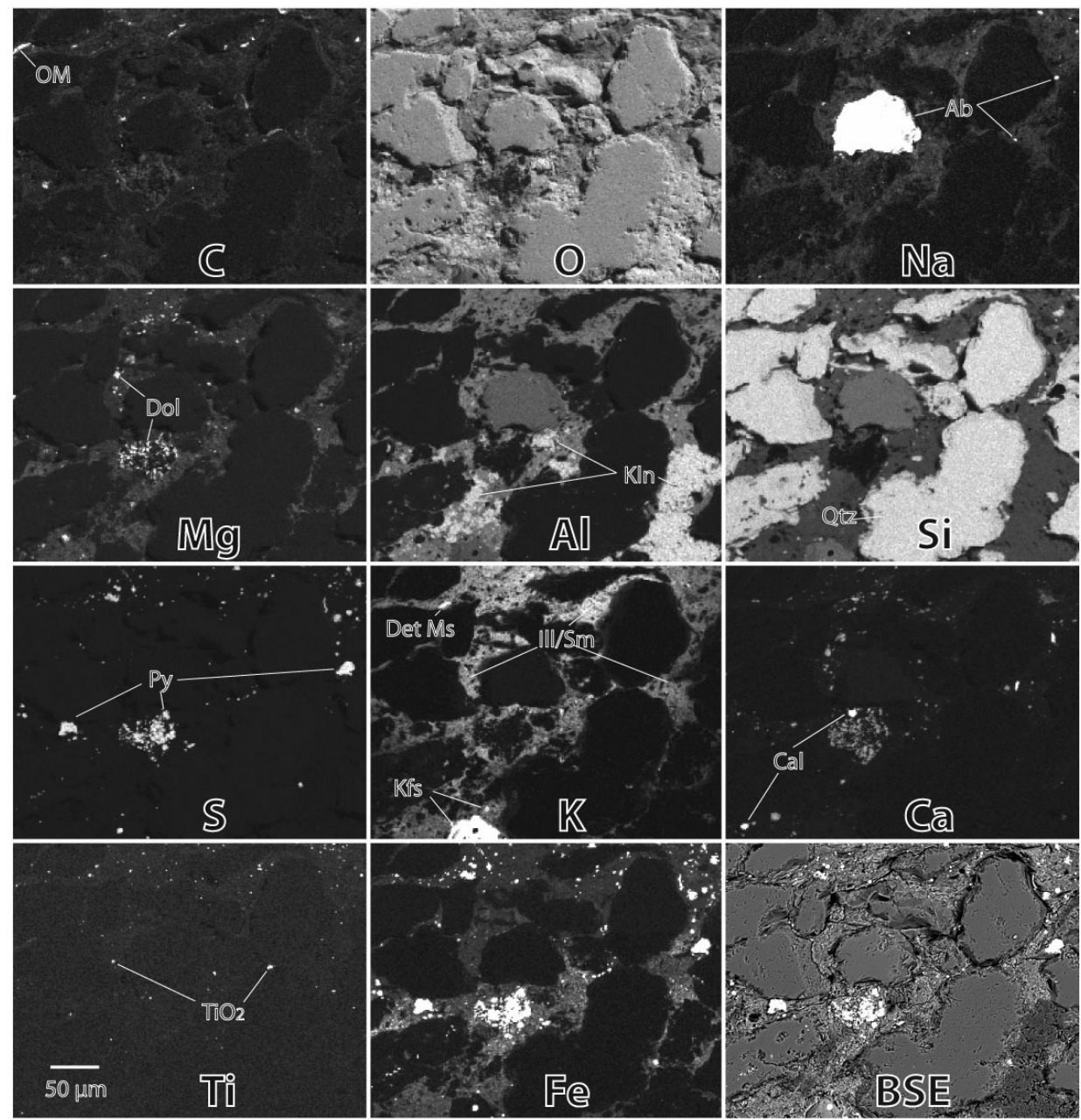

Fig. 7

X-ray maps of a diagenetic grade sample from the Liassic formation Berlingen, Switzerland. BSE = backscattered electron image, $\mathrm{OM}=$ organic matter, Det $\mathrm{Ms}=$ detrital muscovite, and $\mathrm{TiO}_{2}=$ either rutile or anatase

submicrometer sized grains of what appear to be high-Na micas in a sample from Berlingen and one from Lindau (L6) (Frey 1970). The Na content of I/S in diagenetic samples is consistently low at about 0.1 cations per formula unit (cpfu) based on 11 oxygens with only a few exceptions reaching $0.2 \mathrm{cpfu}$. The amount of $\mathrm{Na}$ in $\mathrm{Kln}$ is often the same as that of coexisting I/S $(\sim 0.6 \%)$. These observations indicate that in the diagenetic zone, $\mathrm{Na}$ is distributed throughout the clay matrix in low concentrations, except some isolated areas. If high $\mathrm{Na}$ micas are found in this sample, they are not at the Kln-Ab contacts. Similarly, 
there are no accumulations of high-K Ms found at Kln-Kfs contacts. High-K Ms is found in grains that are likely to be detrital in origin.

Anchizone grade with Kln and Prl. Samples that contain both Kln and Prl in the Central Alps of Switzerland are rare but represent the low anchizonal grade conditions ( $\sim 250{ }^{\circ} \mathrm{C}, 1.5-2$ kbar) (Frey 1987b). The Liassic Black shale that contains this important assemblage is missing, but samples from the closely associated Mürtschen Nappe Mols Formation do contain this assemblage (KB 70/2-2, sample 52 in Frey 1987b). Mixed white mica and rectorite have been also identified by XRPD. The total assemblage identified by Frey (1987b) was Kln + $\mathrm{Prl}+\mathrm{Qtz}+\mathrm{Ill}+\mathrm{Rec}+\mathrm{MWM}+\mathrm{Chl}+\mathrm{Cal}+\mathrm{Dol}+\mathrm{OM}$ making this a low variance assemblage. In addition, Brm, ankerite, detrital $\mathrm{Ms}$, and $\mathrm{Ab}$ were identified by electron petrography (Fig. 8).

The X-ray maps in Fig. 8 show a wonderful example of how complex a phyllosilicate stack can be. The origin of this stack may be deduced from the K map that displays thin remnants of a detrital Ms grain that were pried apart by new growth of other phyllosilicates. The stack now includes Kln, Prl and Fe-rich $\mathrm{Chl}$. The creation of this stack likely began with the alteration of Ms by Kln and possibly Chl. At temperatures above $200^{\circ} \mathrm{C}$, Kln reacted to form Prl till nearly all Kln was consumed, at which point this sample stopped reacting. Sodium-rich phases are not abundant in this sample, but a few Brm grains (identified by semiquantitative EDS analyses with high $\mathrm{Na}$ and low interlayer totals) and isolated $\mathrm{Ab}$ crystals can be seen. White micas in the matrix tend to contain less than $0.1 \mathrm{cpfu} \mathrm{Na}$, similar to lower grade samples. At this grade, samples from the Central Alps have little $\mathrm{Ab}$ and only a few isolated grains of Na-rich WM. Most of the $\mathrm{Na}$ is distributed throughout the matrix WM in low concentrations. The phyllosilicate stacks form after detrital Ms or vermicular Kln books, but do not contain Pg or Brm.

Anchizonal grade above the Kln-Prl isograd (in the sense of Frey 1978). Albite is not abundant in anchizone or epizone grade Liassic metaclastics. Formation of phyllosilicate stacks is common, with the most common assemblage of phyllosilicates being a combination of Ms, Chl and Prl. When Na-rich WM is present, it is most obvious in the stacks as both discrete Pg and MWM. When the Al bulk content is high, di,trioctahedral chlorite (sudoite)(Sud) and di,dioctahedral chlorite (donbassite) (Dbs) are also found in the stacks and in the matrix. Figure 9 is of a sample from Guggenegg (MF 644, Frey 1970) and contains two stacks that are mixtures of Ms, MWM and Dbs. The MWM is often located at the tips of Ms as in the stacks of Fig. 9. However, considerable amounts of Pg are found mixed in with the aluminous chlorites. The texture of Dbs and Pg in the matrix is similar to that of vermicular Kln found in the diagenetic grade samples. Tourmaline forms as an additional high $\mathrm{Al}$ phase containing $\mathrm{Na}$. 


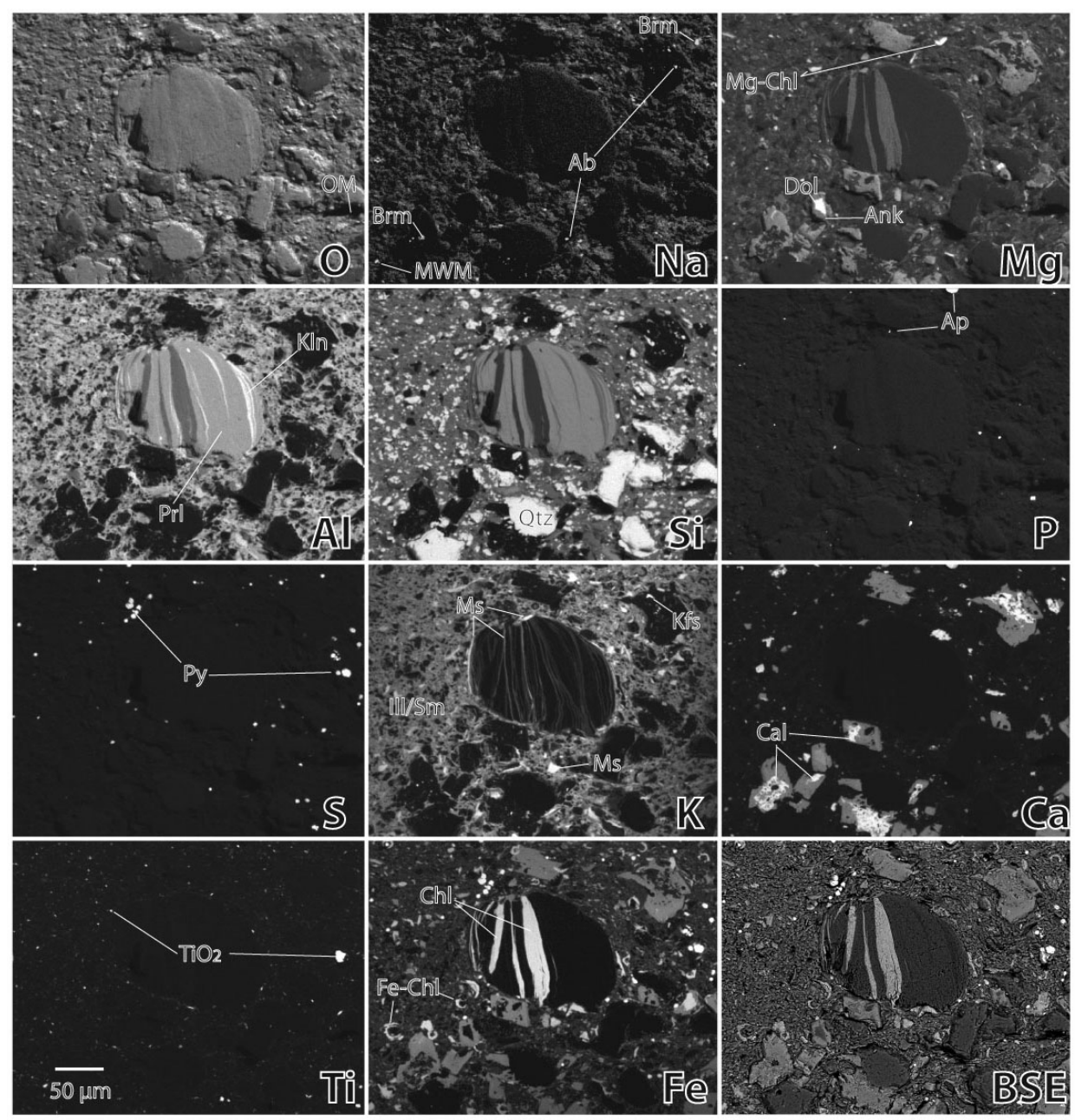

Fig. 8

X-ray maps of an anchizone grade sample at the Kln-Prl isograde from the Mols Formation, Mürtschen Nappe, Switzerland. Abbreviations as in Fig. 7, Ap = apatite

\section{Discussion}

It is well known from the basic principles of metamorphic petrology that there are strict relations between bulk rock chemistries and metamorphic mineral assemblages as a function of the physical conditions of metamorphism. In spite of this, as Fig. 2 shows, there is considerable overlap between the fields of Pgbearing and Pg-free rocks. As a first approximation, these overlaps can be 


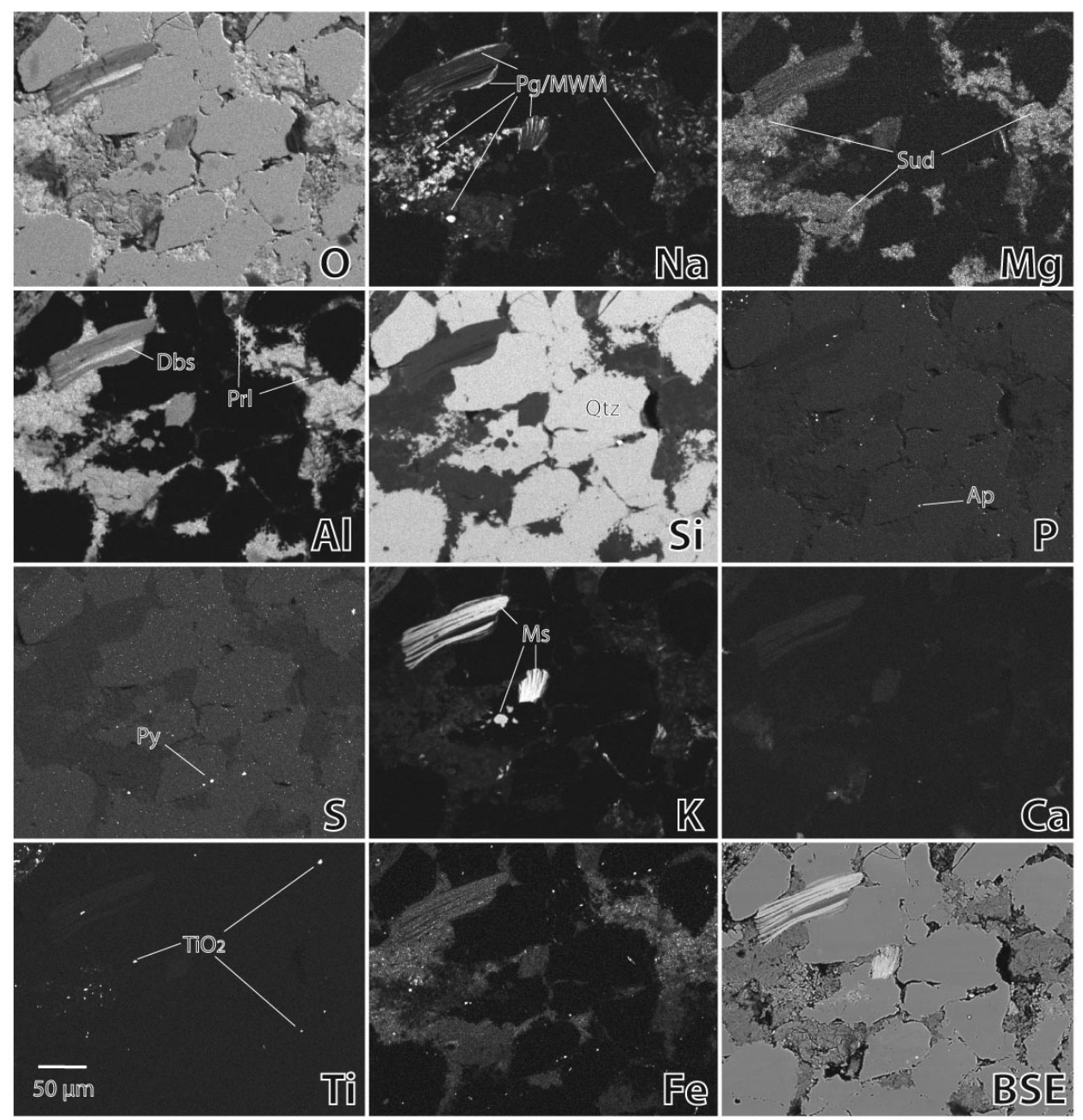

Fig. 9

X-ray maps of an anchizone grade sample above the Kln-Prl isograde from the Liassic formation, Guggenegg, Switzerland. Abbreviations as in Figs 7 and 8, Sud $=$ sudoite and Dbs $=$ donbassite

explained in terms of two major controls, namely either the bulk rock chemistries do not represent the effective chemistries that act during metamorphic mineral reactions (i.e. reactions in domains of various chemical compositions), or other causes (e.g. temperature, pressure, fluid chemistry, etc.) may also be responsible for the formation of Pg. As it was demonstrated in the part 'Results', errors in the projection of the bulk compositions after the applied corrections are insignificant and may not be responsible for these overlaps.

When considering the effects of bulk rock chemistry on the appearance of $\mathrm{Na}$ bearing white micas in low-T metamorphic fine-grained metaclastic rocks, the 
eventual differences between actual bulk rock chemistries analyzed and the effective (active) bulk chemistries that act during metamorphic reactions should not be overlooked. At these relatively low temperatures where diffusion and reaction rates are very slow within mineral solids, some components are effectively inert or inactive. Mineral grains or rock fragments, especially those having large size, may behave completely or partially (i.e. the core of the grain) as inert during metamorphic reactions. Most clastic, detrital quartz, feldspar and mica grains present in fine-grained rocks could be considered inert, and large mineral grains (phenocrysts, phenoclasts) of magmatic origin found in massive igneous intrusive or lava rocks characterized usually by low porosity and permeability could also be expected to be inert. Most probably, this is the main reason why considerable overlap exists between the main element ratios of the Pg-bearing and Pg-free metaclastic rocks studied.

The example of meta-andesite tuff (locality G) demonstrates that major element bulk chemical constraints influence the formation of Pg especially where the protolith was a very fine-grained tuffaceous material devoid of inherited (clastic) terrigenous components, and the primary magmatic constituents of which were fully altered at high-T anchi- and epizonal conditions. These samples unequivocally demonstrated that $\mathrm{Pg}$ had not formed in rocks with high levels of $\mathrm{Na}$. Instead, $\mathrm{Pg}$ appeared in rocks in which the $\mathrm{Na} /\left(\mathrm{Na}+\mathrm{Al}^{*}\right)$ and the $\mathrm{K} /\left(\mathrm{K}+\mathrm{Al}^{*}\right)$ ratios proved to be smaller than in the associated Pg-free rocks (Fig. 4G). Moreover application of the modified AKNa projection after Guidotti and Sassi (1976) demonstrates that neither enrichment in Na nor increase of $\mathrm{Na} / \mathrm{K}$ ratio has favored the formation of $\mathrm{Pg}$ in the studied low-T metamorphic rocks. In spite of the uncertainties of correction for $\mathrm{Chl}$, and possible incorporation of $\mathrm{K}$ in detrital alkali feldspars, the example from locality $\mathrm{F}$ unequivocally proves that enrichment in $\mathrm{Na}$ of a given lithology does not necessarily lead to formation of $\mathrm{Pg}$ or its precursor phases, as stated earlier by Merriman (2002, 2005, 2006). In this albitic claystone neither Pg nor its precursor phases (MWM, brammallite, Nasmectite) have formed despite the very often extremely high bulk rock $\mathrm{Na}_{2} \mathrm{O}$ contents.

There are numerous geologic processes by which bulk rock chemical criteria favoring the formation of $\mathrm{Pg}$ and its precursor phases may be reached or fulfilled in prograde low-T rocks. In the followings the most important ones are briefly discussed.

"Chemical maturation" state (intensity of chemical weathering of the source rocks of the pelitic protoliths). Whether chemical weathering is interpreted by the isovolumetric method (Millot 1970) or by supposing systematic differences in the mobility of the major elements (for a recent summary see Price and Velbel 2003) or by combining these two approaches (Price and Velbel 2003), it is obvious that the relative amount of $\mathrm{Al}$ increases as compared to the other major elements like alkali, alkali-earth elements, $\mathrm{Fe}^{2+}$ and $\mathrm{Si}$ with increasing "chemical maturity" (i.e. with increasing chemical alterations during erosion, material transport and 
sedimentation). Subaerial and subaquatic regions of passive continental margin settings and extensional plate boundary settings characterized by low relief, low rates of erosion and sedimentation - preferably under warm and humid climatic conditions - favor the formation of chemically strongly weathered (Al-rich) sediments, in which MWM and Pg may preferentially form during prograde metamorphism. Although Na-rich micas are not specifically mentioned, the chemical weathering of silicate minerals is characterized by Loughnan (1969) and Degens (1968), and that of muds by Weaver (1989) and Chamley (1989). An upto-date comparative study of chemical weathering indices applied to silicate rocks is given by Price and Velbel (2003).

By contrast, sedimentation in active collisional settings, often characterized by subduction-related accretionary wedges, rapid erosion and rapid accumulation of chemically weakly weathered sedimentary materials (with considerable amounts of feldspars and lithic clasts) are typical. In such clastic (pelitic, silty and arenaceous) rocks bulk chemical relations favor the formation of simple Ms-AbChl-Qtz assemblages. This conclusion confirms the geotectonic interpretation given by Merriman $(2002,2005,2006)$.

Observations on active and fossil hydrothermal alterations of ocean-floor basalts beneath and within hydrothermal mounds shed light on the formation of Pg in such environments. Honnorez et al. (1998) and Alt and Teage (1998) recorded three stages of alteration in a stockwork: 1 . chloritization of the basaltic basement with $\mathrm{Mg}$-bearing hydrothermal solutions $\left(250-370{ }^{\circ} \mathrm{C}\right) ; 2$. replacement of basalt and chloritized basalt by and precipitation of $\mathrm{Pg}+\mathrm{Qtz}+\mathrm{Py}$. Na-rich micas reflect the high $\mathrm{Na} / \mathrm{K}$ ratio of the present-day hydrothermal fluids discharged by the TAG black smokers at temperatures between 260 and $360^{\circ} \mathrm{C}$; and 3. precipitation of anhydrite in open spaces. In oceanic forearc settings Alt et al. (1998) observed so-called "sericitization halos" (Na-K "sericite", Qtz, Prl, Kfs and Py) along Qtzveins at temperatures of $200-250{ }^{\circ} \mathrm{C}$ produced by focused flows of hydrothermal fluids.

Fluid chemistry (including pre- and/or post-metamorphic hydrothermal activity) acts by changing bulk rock chemistries and therefore this aspect will be discussed in relation to bulk chemical changes. According to Merriman (2002, 2005 , 2006), intrusive or extrusive magmatism-related hydrothermal activity may also favor the formation of $\mathrm{Pg}$ and its precursor phases. This activity may pre- or post-date or may be synchronous with regional metamorphism. Such conditions were found to be characteristic of extensional burial settings of the British Lower Paleozoic basins. In these basins - as Merriman (2002, p. 216) wrote - "Low temperature seawater interaction with hydrothermal systems may have been responsible for the reactions that generated the Na-clays. However, Na-clays are not restricted to thermal aureoles in the extensional basins. Their widespread occurrence suggests that fluids with elevated $\mathrm{Na} / \mathrm{K}$ ratios were available basinwide, both during the early stages of burial-related clay diagenesis and very lowgrade metamorphism, and also during the later stages of basin contraction and 
tectonic fabric development in mudrocks. Such fluids were not available in convergent settings, probably through lack of volcanic activity during the early stages of diagenesis and burial metamorphism."

However, the evidence summarized in the present paper suggests that enrichment in $\mathrm{Na}$ and/or increase of $\mathrm{Na} / \mathrm{K}$ ratio of such mixed fluids (and through the fluid-rock interaction - in the rocks themselves) may not necessarily lead to the formation of Na-bearing phyllosilicates. By contrast, relative depletion of alkalis as compared to $\mathrm{Al}$ bound to alkali feldspars, $\mathrm{K}-\mathrm{Na}$ white micas and pure (hydrous or anhydrous) aluminosilicates, i.e. decrease in $\mathrm{Na} /\left(\mathrm{Na}+\mathrm{Al}^{*}\right)$ and $\mathrm{K} /\left(\mathrm{K}+\mathrm{Al}^{*}\right)$ ratios favor and promote the formation of $\mathrm{Pg}$ and $\mathrm{MWM}$. The AKNa projections of bulk rock chemistries - after necessary corrections - support this statement. In addition to the variations in actual chemical composition of hydrothermal fluids or hydrothermal fluid/seawater mixtures (see Von Damm 1995), the selective enrichment or removal of certain chemical elements from the original rocks, i.e. the bulk chemical changes between the original and altered rocks are of decisive importance, according to the present authors' opinion. For example, during the formation of $\mathrm{Pg}+\mathrm{Qtz}+\mathrm{Py}$ zone, "hydrothermally incompatible" elements have been leached away from the basaltic basement, and only $\mathrm{Fe}, \mathrm{S}, \mathrm{Si}, \mathrm{Al}$ and $\mathrm{Na}$ with minor $\mathrm{Cr}$ and Ti remain (Honnorez et al. 1998). For evaluating these changes, chemical net balance (transfer) calculations considering also fluid/rock ratio and the loss/gain in mass and/or volume of solid phases would be necessary, which - taking into account the open nature of such systems - is not an easy problem to be solved in the future.

The example of the hydrothermally altered and weathered phyllites from locality $\mathrm{H}$ also shows that the leaching effect of hydrothermal fluids resulting in relative (residual) enrichment of $\mathrm{Al}$ as compared to other, much more mobile rock-forming elements may be the main cause of formation of Na-bearing micas. This conclusion can also be confirmed by the fact that Pg and mixed K-Na-micas are associated both in the Welsh Basin (Merriman 2002, 2006) and in locality H with Prl, and Kln and Hys, respectively. However, crystallization regimes characterized by high alkali $(\mathrm{Na})$ content would not have promoted the formation of these alkali-free phyllosilicates.

Considering temperature, the grades of the studied sample sets vary between deep or late diagenesis and the epizone (sub-biotite, low-T part of the greenschist facies), i.e. between ca. 200 and $400{ }^{\circ} \mathrm{C}$. In this $\mathrm{T}$ interval the domainal reaction progress model outlined and developed by Livi et al. $(1990,1997,2008)$ explains fairly well the continuous ordering and segregation mechanisms of dioctahedral micas with mixed interlayer occupancy towards discrete $\mathrm{Ms}$ and $\mathrm{Pg}$ phases. Consequently, changes in temperature in the given range may be responsible for the order-disorder relations and segregation of $\mathrm{K}$ - and Na-rich dioctahedral micas, but cannot be related to the occurrence or absence of the Na-rich micas.

Relatively few data can be found in the literature on the preferential formation and occurrences of Pg in metaclastic rocks at high pressures. In Al-rich metamarls 
$\mathrm{Pg}+\mathrm{Zo}+\mathrm{Qtz}$ assemblage characteristic of high-P forms at the expenses of Pl + $\mathrm{Mrg}+\mathrm{H}_{2} \mathrm{O}$ (Franz and Althaus 1977 in Winkler 1979). As Winkler (1979) wrote of metapelites, "any albite and $\mathrm{K}$ feldspar in contact with pyrophyllite will react to form paragonite and muscovite (phengite), respectively; commonly a mixedlayer paragonite/muscovite is also formed". In very low-grade metabasites the Ep $+\mathrm{Chl}+\mathrm{Ab}+\mathrm{Qtz}=\mathrm{Lws}+\mathrm{Cro}+\mathrm{Pg}$ reaction takes places with increasing $\mathrm{P}$ (Brown 1977, in Winkler 1979). The very low-grade formation of Pg at high P in the Lws-Gln zone was known also to Chatterjee (1971, in Winkler 1979). As summarized by Bucher and Frey (2002), Pg occurs also in greenschists at high pressures. The P-T relations of the reaction $\mathrm{Chl}+\mathrm{Zo}+\mathrm{Ab}+\mathrm{Qtz}=\mathrm{Tr}+\mathrm{Pg}+$ $\mathrm{H}_{2} \mathrm{O}$ are extremely sensitive to small changes in bulk rock chemistry.

The THERMOCALC calculations presented here in the NKFMASH system provided new data on the mineral chemical and P-T variations for Ab-and Pg-out reaction lines and determined the stability fields of the Chl-Ms-Pg, Chl-Ms-Pg-Ab and Chl-Ms- $\mathrm{Ab}$ assemblages in metapelites characterized by strongly different $\mathrm{Al}_{2} \mathrm{O}_{3}$ contents and $\mathrm{Na} / \mathrm{Al}$ and $\mathrm{K} / \mathrm{Al}$ ratios. As Fig. 6 shows, Pg-bearing assemblages form only in Al-rich (and alkali-poor) lithologies. The order of localities from $\mathrm{B}$ to $\mathrm{F}$ expresses the decrease of $\mathrm{Al}$ and increases of $\mathrm{Na}$ and $\mathrm{K}$ contents in general. Accordingly, the stability field of the Chl-Ms-Pg assemblage decreases and is shifted towards higher pressures, and are often replaced, completed or combined by other, high-P minerals like Gln and Jd in this order The same trend is valid also for the Chl-Ms-Pg-Ab assemblage. The stability field of the Chl-Ms-Ab assemblage (being the most common in low- and medium-P very low- and low-grade metapelites) becomes larger and is shifted towards lower temperatures. In the locality $\mathrm{F}$ (being richest in $\mathrm{Na}$ and having high $\mathrm{Na} / \mathrm{Al}$ ratios) no Pg is stable according to the thermodymanic calculations.

In some of the samples $\mathrm{Ab}$ breaks down to $\mathrm{Pg}$ (or vice versa) via continuous reactions in the assemblage Chl-Ms-Pg-Ab, while in the other ones $\mathrm{Pg}$ is not present, so Ab is replaced by Gln or Jd. For the Pg-out line there is a general shift in pressure values from sample RT2 to sample Sz-22 (from $1.51 \mathrm{kbar}$ to $8.95 \mathrm{kbar}$ at $\left.400{ }^{\circ} \mathrm{C}\right)$.

The above discussions have centered on the effects of bulk composition on the mineral assemblage while having in mind that mineral solids will have varying degrees of participation in determining that bulk composition. Examination of the rock textures and elemental distributions may lead to an understanding of the spatial extent of domains that define the degree of local equilibration.

The concept of local equilibrium was described by Korzhinskii (1959 and earlier works) and introduced to the western geologic community by Thompson (1959). Thompson (1959) stated that "equilibrium will tend to be maintained locally even though the system as a whole may be distinctly out of equilibrium". Darken (1942) described this phenomenon as "microscopic reversibility". Taken at face value, this concept may lead to the assumption that the smaller the scale of observation, the more likely one would find equilibrium assemblages. However, 
the ability of components to transport to and from and participate at a particular reaction site must also be accounted for.

It is therefore more useful to define a frame of reference within which a component is free to transport, react and equilibrate. This requires the defining of an "effective" bulk composition (EBC) and a communication distance (CD) that in turn would determine the set of reactions that are stable. The $\mathrm{CD}$ is a function of: 1) transport rates in both the solid and intergranular medium, 2) reaction rates at the solid interface, and 3) time. Rates 1 and 2 are themselves a function of temperature along with many other factors. Transport can be either by diffusion or advection. If we stay at small scales of observation (that of a thin section), and in low permeability rocks such as shales, then diffusion will dominate.

It should be noted that since the diffusivities of components are likely to vary, the EBC and CD for each component will be different. Similarly, the diffusivity of a component will be different in a solid as opposed to the intergranular medium. The intergranular medium itself is a complex arrangement of grain boundary configurations where there are likely to be fast and slow transport channels. Thus, the size of the CD is impossible to predict for any given rock. However, observations show that micas tend to homogenize with increasing metamorphic grade (Livi et al. 1997), and therefore, it can be assumed that the size of the CD will increase with increasing metamorphic grade.

If we apply these concepts to the textural observations of $\mathrm{Na}$ distribution in the Liassic shale, one important conclusion can be reached. If transport of $\mathrm{Na}$ was restricted to an area containing only a few grains in contact with each other, then $\mathrm{Pg}$ formation would occur at Ab-phyllosilicate boundaries. In fact, $\mathrm{Na}$ is widely spread throughout the matrix grains in low concentrations. When Pg forms, heterogeneous nucleation occurs in and on existing phyllosilicates. Mixed white micas with high $\mathrm{Na}$ content are formed metastably and discrete Pg forms from these MWM and as new growth on the surfaces of other phyllosilicates. This highlights the inability of Pg to nucleate homogeneously.

While Pg has trouble nucleating, $\mathrm{Na}$ apparently can diffuse away from its main source, $\mathrm{Ab}$. This would increase the $\mathrm{CD}$ of $\mathrm{Na}$ and lends credibility to the notion that hand sample bulk rock compositions can predict whether Pg should form. It is also apparent that even at diagenetic grades, $\mathrm{Na}$ is diffusing through the intergranular medium. Thus, transport in the grain boundaries is much faster than in the solids. This creates a potential for the thorough mixing and homogenization of the fluid composition to which each solid particle is reacting with. Therefore, while any solid grain will react locally with the intergranular medium, the intergranular medium derives its composition from more distant sources. The system could then be described as slowly diffusing and reacting solids within an infinite reservoir (Livi et al. 2002).

This description validates the concept of bulk chemical controls on Pg formation with the qualifier that, at low temperatures, the EBC consists mainly of a latticework of mineral interfaces connected by the intergranular medium. 
During the lowest grades of evolution, dissolution-precipitation processes are likely to dominate over diffusion-controlled chemical changes in the solids. As the temperature increases, diffusion in the solid speeds up, equilibration between solid interfaces and cores will progress, bringing more of the solids in communication with the EBC. In this way, the EBC changes with grade as the CD changes in both the solids and fluid.

\section{Conclusions}

The formation of $\mathrm{Pg}$ has been shown to be a function of the bulk composition and a few examples of the temperature and pressure effects on Pg stability have been demonstrated. These thermodynamic controls are modified by kinetic processes that inhibit the homogeneous nucleation of $\mathrm{Pg}$ and define an evolving effective bulk composition. Taken together, they describe a more realistic process of $\mathrm{Pg}$ formation. Since bulk composition is paramount to Pg formation, those geologic processes that effect the initial sedimentary composition (provenance, degree of weathering) or that modify it by metasomatism will ultimately control the presence or absence of paragonite.

\section{Acknowledgements}

The authors are grateful to Dr. R.J. Merriman for the critical advice, corrections and suggestions given to the first draft. Thanks are due to Dr. István Viczián, Dr. Kálmán Török and an anonymous reviewer for critically improving the manuscript. The present work forms a part of the first author's metamorphic petrological research program financially supported by grant No. T-049454 of the Hungarian Research Fund (OTKA), Budapest.

\section{References}

Alt, J.C., D.A.H. Teagle 1998: Probing the TAG hydrothermal mound and stockwork: oxygen-isotope profiles from deep ocean drilling. - In: Herzig, P.M., S.A. Humphris, D.J. Miller, R.A. Zierenberg (Eds): Proceedings of the Ocean Drilling Program. Scientific Results, 158, pp. 285-295.

Alt, J.C., D.A.H. Teagle, T. Brewer, W.C. (III) Shanks, A. Halliday 1998: Alteration and mineralization of an oceanic forearc and the ophiolite-ocean crust analogy. - Journal of Geophysical Research, 103, pp. 12365-12380.

Árkai, P. 1977: Low-grade metamorphism of Paleozoic formations of the Szendrô Mountains (NE Hungary). - Acta Geologica Academiae Scientarium Hungaricae, 21, pp. 53-80.

Árkai, P. 1982: Incipient regional metamorphism (on the examples of the Bükk, Uppony and Szendrô Mts., NE-Hungary). - Candidate of Science (PhD) Thesis, Budapest. (In Hungarian.)

Árkai, P. 1983: Very low- and low-grade Alpine regional metamorphism of the Paleozoic and Mesozoic formations of the Bükkium, NE-Hungary. - Acta Geologica Hungarica, 26, pp. 83-101.

Árkai, P. 2002: Phyllosilicates in very low-grade metamorphism: Transformation to micas. - In: Mottana, A., F.P. Sassi, J.B. Thompson Jr., S. Guggenheim (Eds): Micas: Crystal Chemistry and 
Metamorphic Petrology. - Reviews in Mineralogy and Geochemistry, Mineralogical Society of America, Washington, 46, pp. 463-478.

Árkai, P., S. Kovács 1986: Diagenesis and regional metamorphism of the Mesozoic of Aggtelek-Rudabánya Mountains (Northeast Hungary). - Acta Geologica Hungarica, 29, pp. 349-373.

Árkai, P., Gy. Lelkes-Felvári 1993: The effects of lithology, bulk chemistry and modal composition on illite "crystallinity" - A case study from the Bakony Mts., Hungary. - Clay Minerals, 28, pp. 417-433.

Árkai, P., D. Sadek Ghabrial 1997: Chlorite crystallinity as an indicator of metamorphic grade of lowtemperature meta-igneous rocks: A case study from the Bükk Mountains, northeast Hungary. Clay Minerals, 32, pp. 205-222.

Árkai, P., K. Balogh, I. Dunkl 1995: Timing of low-temperature metamorphism and cooling of the Paleozoic and Mesozoic formations of the Bükkium, innermost western Carpathians, Hungary. - Geologische Rundschau, 84, pp. 334-344.

Árkai, P., K. Balogh, A. Demény, I. Fórizs, G. Nagy, Z. Máthé 2000a: Composition, diagenetic and post-diagenetic alterations of a possible radioactive waste repository site: the Boda Albitic Claystone Formation, southern Hungary. - Acta Geologica Hungarica, 43, pp. 351-378.

Árkai, P., M.P. Mata, G. Giorgetti, D.R. Peacor, M. Tóth 2000b: Comparison of diagenetic and lowgrade metamorphic evolution of chlorite in associated metapelites and metabasites: an integrated TEM and XRD study. - Journal of Metamorphic Geology, 18, pp. 531-550.

Árkai, P., G. Christidis, E. Manutsoglu, P. Horváth 2001: Preliminary results on the phyllosilicate reaction progress in the Permo-Triassic Ravdoucha (Tyros) beds of the External Hellenides (Crete, Greece). - In: Mid-European Clay Conference '01, September 9-14 2001, Stará Lesná Slovakia, Book of abstracts, p. 3.

Árkai, P., S.W. Faryad, O. Vidal, K. Balogh 2003: Very low-grade metamorphism of sedimentary rocks of the Meliata unit, Western Carpathians, Slovakia: implications of phyllosilicate characteristics. - International Journal of Earth Sciences, 92, pp. 68-85.

Bucher, K., M. Frey 2002: Petrogenesis of metamorphic rocks. 7th edition. - Springer, Berlin, etc., p. 339.

Chamley, H. 1989: Clay sedimentology. - Springer-Verlag, Berlin, etc., 623 p.

Chatterjee, N.D. 1973: Low-temperature compatibility relations of the assemblage quartz-paragonite and the thermodynamic status of the phase rectorite. - Contributions to Mineralogy and Petrology, 42, pp. 259-271.

Christidis, G., E. Manutsoglu, P. Árkai 2003: K-, Na- and mixed K-Na-white micas in the Ravdoucha (Tyros) Beds and the Quartzite-Phyllite Formation, Crete: an indication for disequilibrium conditions of very low-temperature metamorphism. - EUROCLAY 2003 - 10th Conference of the European Clay Groups Association, Modena, Italy, June 22-26 2003, Abstracts, p. 66.

Christidis, G., E. Manutsoglu, K.J.T. Livi, P. Árkai, P. Horváth: Na-rich micas in the anchizonal metamorphic Ravdoucha beds, Western Crete, Greece. - Submitted to the European Journal of Mineralogy.

Coggon, R., T.J.B. Holland 2002: Mixing properties of phengitic micas and revised garnet-phengite thermobarometers. - Journal of Metamorphic Geology, 20, pp. 683-696.

Connolly, J.A.D. 1990: Multivariable phase diagrams: an algorithm based on generalized thermodynamics. - American Journal of Science, 290, pp. 666-718.

Connolly, J.A.D., K. Petrini 2002: An automated strategy for calculation of phase diagram sections and retrieval of rock properties as a function of physical conditions. - Journal of Metamorphic Geology, 20, pp. 697-708.

Darken, L.S. 1942: Diffusion in metal accompanied by phase change. - Transactions of the American Institute of Mining and Metallurgical Engineering, 150, pp. 151-171.

Degens, E.T. 1968: Geochemie der Sedimente. - Ferdinand Enke Verlag, Stuttgart, p. 282.

Foster, M.D. 1962: Interpretation of the composition and a classification of the chlorites. Professional papers of the U.S. Geological Survey, 414-A, pp. 1-33. 
Frey, M. 1969: A mixed-layer paragonite/phengite of low-grade metamorphic origin. - Contributions to Mineralogy and Petrology, 14, pp. 63-65.

Frey, M. 1970: The step from diagenesis to metamorphism in pelitic rocks during Alpine orogenesis. - Sedimentology, 15, pp. 261-279.

Frey, M. 1978: Progressive low-grade metamorphism of a black shale formation, Central Swiss Alps, with special reference to pyrophyllite and margarite bearing assemblages. - Journal of Petrology, 19, pp. 95-135.

Frey, M. 1987a: Very low-grade metamorphism of clastic sedimentary rocks. - In: Frey, M. (Ed.): Low Temperature Metamorphism. - Blackie, Glasgow, pp. 9-58.

Frey, M. 1987b: The reactions-isograd kaolinite + quartz $=$ pyrophyllite $+\mathrm{H}_{2} \mathrm{O}$, Helvetic Alps, Switzerland. - Schweizerische Mineralogische und Petrographische Mitteilungen, 67, pp. 1-11.

Guidotti, C.V., F.P. Sassi 1976: Muscovite as a petrogenetic indicator mineral in pelitic schists. - Neues Jahrbuch für Mineralogie, Abhandlungen, 127, pp. 97-142.

Guidotti, C.V., F.P. Sassi 1998: Petrogenetic significance of Na-K white mica mineralogy: recent advances for metamorphic rocks. - European Journal of Mineralogy, 10, pp. 815-854.

Holland, T.J.B., J. Barker, J.R. Powell 1998: Mixing properties and activity-composition relationships of chlorites in the system $\mathrm{MgO}-\mathrm{FeO}-\mathrm{Al}_{2} \mathrm{O}_{3}-\mathrm{SiO}_{2}-\mathrm{H}_{2} \mathrm{O}$. - European Journal of Mineralogy, 10, pp. 395-406.

Holland, T.J.B., R. Powell 1998: An internally consistent thermodynamic data set for phases of petrological interest. - Journal of Metamorphic Geology, 16, pp. 309-343.

Honnorez, J.J., J.C. Alt, S.E. Humphris 1998: Vivisection and autopsy of active and fossil hydrothermal alterations of basalt beneath and within the TAG hydrothermal mound. - In: Herzig, P.M., S.A. Humphris, D.J. Miller, R.A. Zierenberg (Eds): Proceedings of the Ocean Drilling Program, Scientific Results, 158, pp. 231-254.

Jiang, W-T., D.R. Peacor 1993: Formation and modification of metastable intermediate sodium potassium mica, paragonite and muscovite in hydrothermally altered metabasites from northern Wales. - American Mineralogist, 78, pp. 782-793.

Kisch, H.J., R. Sassi, F.P. Sassi 2006: The $b_{\mathrm{o}}$ lattice parameter and chemistry of phengites from HP/LT metapelites. - European Journal of Mineralogy, 18, pp. 207-222.

Koroknai, B., P. Árkai, P. Horváth, K. Balogh 2008: Anatomy of a transitional brittle-ductile shear zone developed in a low-T meta-andesite tuff: A microstructural, petrological and geochronological case study from the Bükk Mts. (NE Hungary). - Journal of Structural Geology, 30, pp. 159-176.

Korzhinskii, D.S. 1959: Physicochemical basis of the analysis of the paragenesis of minerals. Consultants Bureau, Inc. New York, 142 p.

Laird, J. 1988: Chlorites: metamorphic petrology. - In: Bailey, S.E. (Ed.): Hydrous phyllosilicates (exclusive of micas)". - Reviews in Mineralogy, Mineralogical Society of America, Washington 19, pp. 405-453.

Li, G., D.R. Peacor, R.J. Merriman, B. Roberts 1994: The diagenetic to low-grade metamorphic evolution of matrix white micas in the system muscovite-paragonite in a mudrock from Central Wales, United Kingdom. - Clays and Clay Minerals, 42, pp. 369-381.

Livi, K.J.T., D.R. Veblen, J.M. Ferry 1990: Segregation of K- and Na-rich micas in low-grade metamorphosed shale from the Liassic black shale, Switzerland. - IGCP Project No. 294: Very low-grade metamorphism. Conference on Phyllosilicates as Indicators of Very Low Grade Metamorphism and Diagenesis. Programme and Abstracts. Manchester, July 1990.

Livi, K.J.T., D.R. Veblen, J.M. Ferry, M. Frey 1997: Evolution of 2:1 layered silicates in low-grade metamorphosed Liassic shales of Central Switzerland. - Journal of Metamorphic Geology, 15, pp. 323-344.

Livi, K.J.T., J.M. Ferry, L. Hinnov, D.R. Veblen, M. Frey 2002: Mineral homogenization during lowtemperature metamorphism: Part 1 Numerical models. - Swiss Bulletin of Mineralogy and Petrology, 82, pp. 151-182. 
Livi, K.J.T., G.E. Christidis, P. Árkai, D.R. Veblen 2008: White mica domain formation: a model for paragonite, margarite, and muscovite formation during prograde metamorphism. - American Mineralogist, 93, pp. 520-527.

Loughnan, F.C. 1969: Chemical weathering of the silicate minerals. - American Elsevier Publishing Company, Inc., New York, p. 154.

Merriman, R.J. 2002: Contrasting clay mineral assemblages in British Lower Palaeozoic slate belts: the influence of geotectonic setting. - Clay Minerals, 37, pp. 207-219.

Merriman, R.J. 2005: Clay minerals and sedimentary basin history. - European Journal of Mineralogy, 17, pp. 7-20.

Merriman, R.J. 2006: Clay mineral assemblages in British Lower Paleozoic mudrocks. - Clay Minerals, 41, pp. 473-512.

Merriman, R.J., M. Frey 1999: Patterns of very low-grade metamorphism in metapelitic rocks. - In: Frey, M., D. Robinson (Eds): Low-Grade Metamorphism. Blackwell Science, Oxford, pp. 61-107.

Merriman, R.J., D.R. Peacor 1999: Very low-grade metapelites: mineralogy, microfabrics and measuring reaction progress. - In: Frey, M., D. Robinson (Eds): Low-Grade Metamorphism. Blackwell Science, Oxford, pp. 10-60.

Millot, G. 1970: Geology of Clays. - Springer-Verlag, New York, etc.

Powell, R., T.J.B. Holland, B. Worley 1998: Calculating phase diagrams involving solid solutions via non-linear equations, with examples using THERMOCALC. - Journal of Metamorphic Geology, 16 , pp. $577-588$.

Powell, R., T.J.B. Holland 1999: Relating formulations of the thermodynamics of mineral solid solutions: activity modeling of pyroxenes, amphiboles and micas. - American Mineralogist, 84, pp. 1-14.

Price, J.R., M.A. Velbel 2003: Chemical weathering indices applied to weathering profiles developed on heterogeneous felsic metamorphic parent rocks. - Chemical Geology 202, pp. 397-416.

Proyer, A. 2003: Metamorphism of pelites in NKFMASH - a new petrogenetic grid with implications for the preservation of high-pressure mineral assemblages during exhumation. - Journal of Metamorphic Geology, 21, pp. 493-509.

Siivola, J., R. Schmid 2007: List of mineral abbreviations. - In: Fettes, D., J. Desmons (Eds): Metamorphic rocks. A classification and glossary of terms. Recommendations of the International Union of Geological Sciences Subcommission on the Systematics of Metamorphic Rocks. - Cambridge University Press, Cambridge, pp. 93-110.

Spear, F.S. 1995: Metamorphic phase equilibria and pressure-temperature-time paths. - Mineralogical Society of America Monograph, 2nd (corrected printing), Washington, D.C., 799 p.

Thompson, A.B. 1974: Calculation of muscovite-paragonite-alkali feldspar phase relations. Contribution to Mineralogy and Petrology, 44, pp. 173-194.

Thompson, J.B., Jr. 1959: Local equilibrium in metasomatic processes. - In: Abelson, P.H. (Ed.): Researches in Geochemistry. - John Wiley and Sons, Inc., New York, pp. 427-457.

Thompson, J.B., Jr. 1961: Mineral facies in pelitic schists. - In: Sokolov, G.A. (Ed.): Physico-chemical problems in the formation of rocks and mineral deposits. Akad. Nauk. SSSR, Moscow, pp. 315-325.

Thompson, J.B., Jr., A.B. Thompson 1976: A model system for mineral facies in pelitic schists. Contribution to Mineralogy and Petrology, 58, pp. 243-277.

Von Damm, K.L. 1995: Controls on the chemistry and temporal variability of seafloor hydrothermal fluids. - In: Humphris, S.E., R.A. Zierenberg, L.S. Mullineaux, R.E. Thomson (Eds): Seafloor hydrothermal system: physical, chemical, biological and geological interactions. - American Geophysical Union, 91, pp. 222-247.

Weaver, C.E. 1989: Clays, Muds and Shales. - Elsevier, Amsterdam-Oxford-New York-Tokyo, 819 p.

Winkler, H.G.F. 1979: Petrogenesis of Metamorphic Rocks. 5th edition. - Springer, New York, Heidelberg, Berlin, $348 \mathrm{p}$.

Zen, E-An 1960: Metamorphism of lower Paleozoic rocks in the vicinity of the Taconic range in Westcentral Vermont. - American Mineralogist, 45, pp. 129-175. 